NBSIR 77-1285(R)

Report of Operating

Experiences in Coal

Conversion Plants

Material of Construction -

Incoloy $\mathbf{8 0 0}$

William A. Willard

John H. Smith

Failure Prevention Information Center Institute for Materials Research

National Bureau of Standards

Washington, D.C. 20234

Summary Report

December 1977

This work was sponsored by

Department of Energy

Washington, D.C. 20545 



\section{REPORT OF OPERATING \\ EXPERIENCES IN COAL \\ CONVERSION PLANTS}

Material of Construction Incoloy $\mathbf{8 0 0}$

William A. Willard

John H. Smith

Failure Prevention Information Center Institute for Materials Research National Bureau of Standards

Washington, D.C. 20234

Summary Report

December 1977

This work was sponsored by

Department of Energy

Washington, D.C. 20545

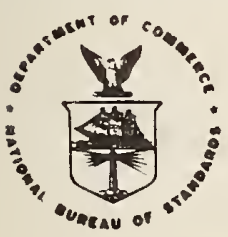

U.S. DEPARTMENT OF COMMERCE, Juanita M. Kreps, Secretary

Dr. Sidney Harman. Under Secretary

Jordan J. Baruch. Assistant Secretary for Science and Technology

NATIONAL BUREAU OF STANDARDS. Ernest Ambler, Acting Director 

This report was prepared as an account of work sponsored by the United States Government. Neither the United States nor the Energy Research and Development Administration, nor any of their employees, nor any of their contractors, subcontractors, or their employees, makes any warranty, express or implied, or assumes any legal liability or responsibility for the accuracy, completeness or usefulness of any information, apparatus, product or process disclosed, or represents that its use would not infringe privately owned rights.

Certain trade names and company products are identified in order to adequately describe the effect of the coal conversion processes on materials and components. In no case does such identification imply recommendation or endorsement by the National Bureau of Standards, nor does it imply that the products are necessarily the best available for the purpose. 

Foreword

The NBS Failure Prevention Information Center is a centralized computerbased system for gathering, critically evaluating, and disseminating information about operating experiences, material evaluation, and component failures in coal conversion plants. Information sources include the coal conversion process development units and pilot plants and ERDA sponsored laboratories conducting diagnostic failure analyses. The objective of this program is to establish a reliable data base of component malfunctions and materials performance which will be useful in extending the lifetimes and reliability of plant components and which will help minimize the possibility of plant shutdowns.

An information gathering network has been developed for the reporting of all significant operating incidents and component failures to the NBS Failure Prevention Information Center. The reports are reviewed and evaluated for completeness and accuracy. A detailed technical summary is prepared of each incident and the information is indexed by process, date, material, failure mode, component category, and information source. The technical summary and indexed information are stored on a computer database management system (Computer Corporation of America Model 204) for ease of retrieval and analysis. This information is analyzed to identify significant problem areas, to determine corrective actions for solving component problems, and to conduct failure mode analyses for coal conversion plants.

It is especially intended that the information in the data base reach plant designers and plant operators. However, access to the Information Center is available to all interested parties. The information in the data base is being disseminated in several ways. All direct inquiries to the Information Center are answered. Reports of failures and summaries of diagnostic failure analysis reports are published in the ERDA Newsletter, Materials and Components in Fossil Energy Applications(1), which is published. bimozthly. This report is an example of the type of sumary reports of operating experiences that will be prepared and issued by the Failure Prevention Information Center with emphasis on failure mode, materials of construction and plant components.

(I) The Newsletter is published by Battelle, Columbus Labs, 505 King Avenue, Columbus, Ohio 43201. Editor: R. Schorr. 


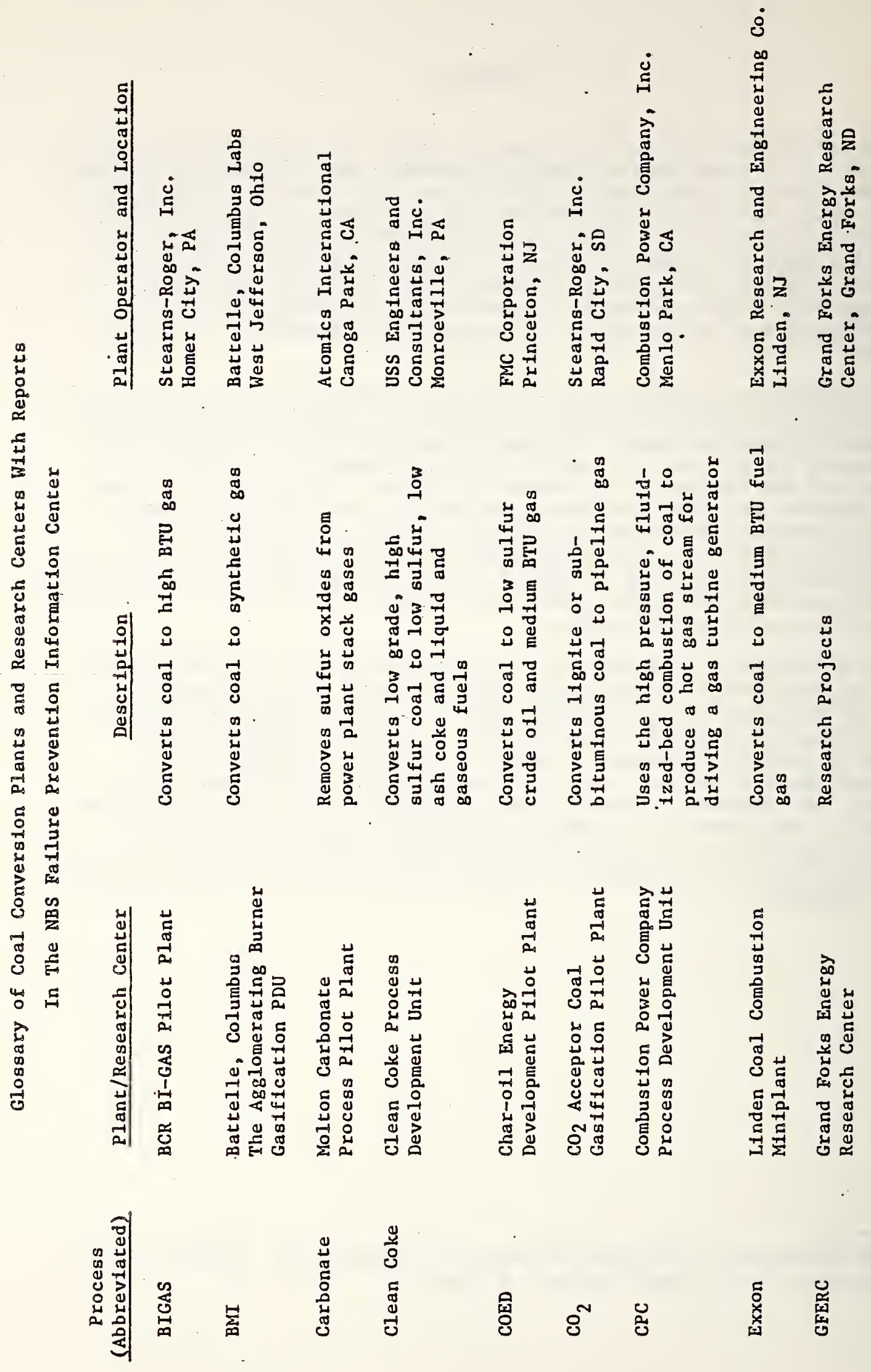




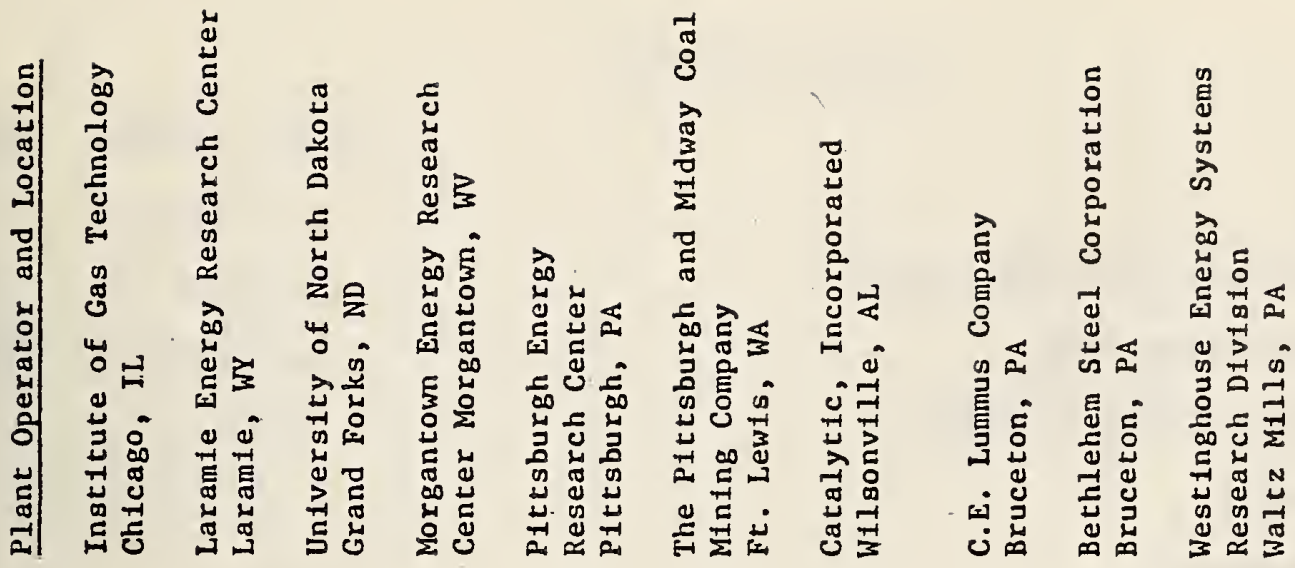

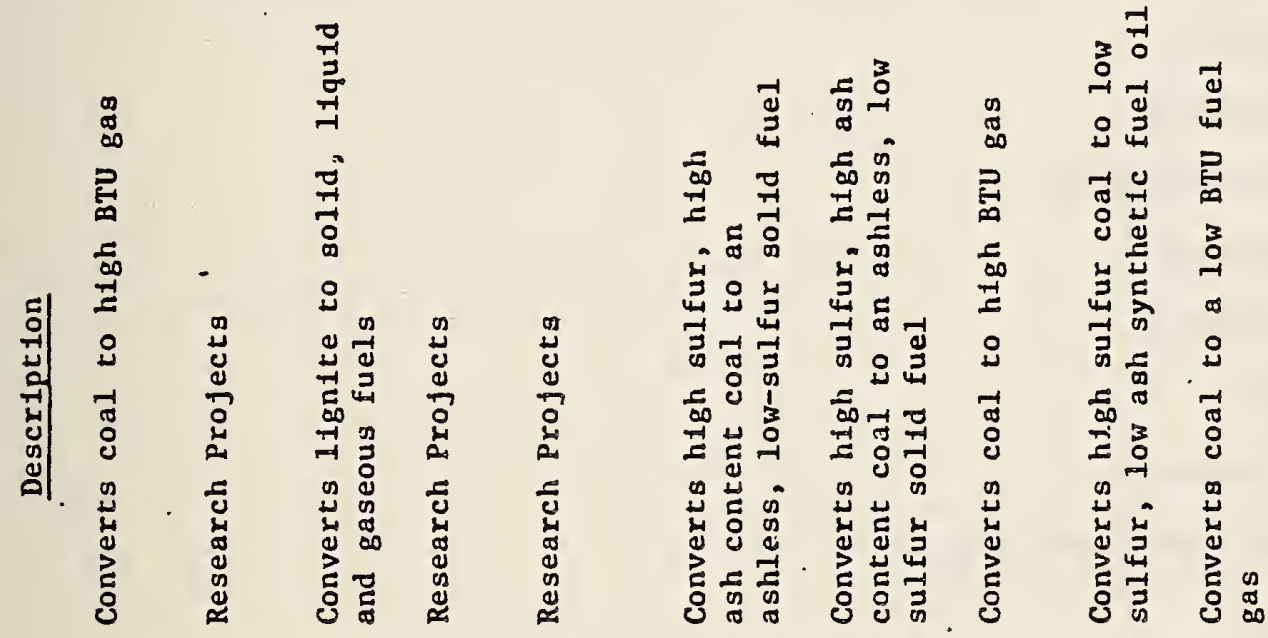

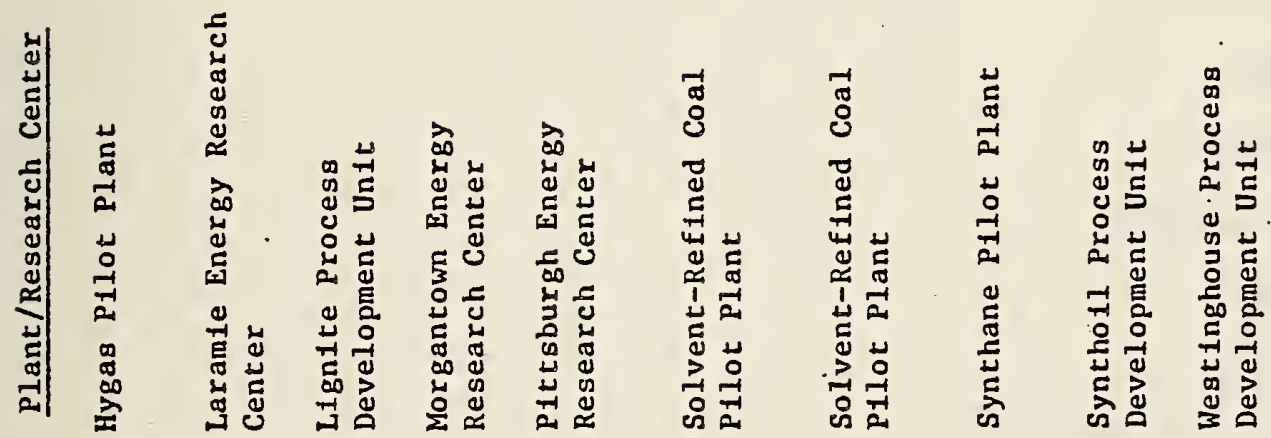

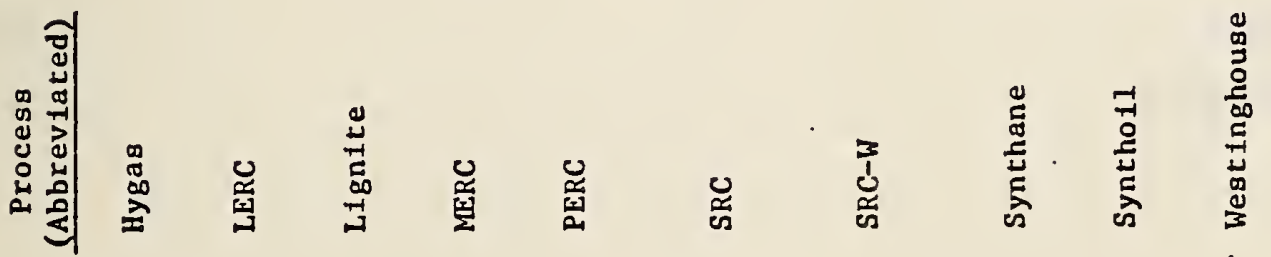


FOREWORD

Page

III

GLOSSERY OF COAL CONVERSION PLANTS

INFORMATION NUMBER INDEX

I. AUXILIARY PROCESS EQUIPMENT

1. Hygas

2. Synthane

3. Syntholl

4. Westinghouse

II. MATERIAL EVALUATION

1. Carbonate

2. Clean Coke

3. COED

4. $\mathrm{CO}_{2}$ Acceptor

5. Combustion Power Company

6. Hygas

7. Solvent Refined Coal

III. PIPING

1. Hygas

2. Synthane

3. $\mathrm{CO}_{2}$ Acceptor

4. Hygas

5. Lignite

6. Solvent Refined Coal

7. Synthane

8. Westinghouse 
IV. PRESSURE VESSELS

I. Hygas

2. Synthane

V. THERMOCOUPLES

1. Synthane

VI. VALVES

I. $\mathrm{CO}_{2}$ Acceptor 
INFORMATION NUMBER INDEX

\begin{tabular}{|c|c|c|c|c|c|}
\hline $\begin{array}{l}\text { Information } \\
\text { Number }\end{array}$ & $\begin{array}{l}\text { Page } \\
\text { Number }\end{array}$ & $\begin{array}{l}\text { Information } \\
\text { Number }\end{array}$ & $\begin{array}{l}\text { Page } \\
\text { Number }\end{array}$ & $\begin{array}{l}\text { Information } \\
\text { Number }\end{array}$ & $\begin{array}{l}\text { Page } \\
\text { Number }\end{array}$ \\
\hline 1 & 19 & 169 & 12 & 341 & 54 \\
\hline 13 & $3,23,45$ & 176 & 36 & 344 & 28 \\
\hline 20 & 15 & 180 & 14 & 351 & 40 \\
\hline 22 & 15 & 182 & 11 & 353 & 40 \\
\hline 26 & 20 & 183 & 12 & 365 & 29 \\
\hline 56 & 17 & 191 & 6 & 366 & 18 \\
\hline 79 & 19 & 194 & 26 & 370 & 38 \\
\hline 88 & 30 & 205 & 25 & 377 & 46 \\
\hline 89 & 30 & 210 & 24 & 378 & 5 \\
\hline 93 & 31 & 213 & 23 & 393 & 48 \\
\hline 94 & 31 & 220 & 27 & 398 & 47 \\
\hline 95 & 32 & 224 & 37 & 399 & 48 \\
\hline 99 & 16 & 236 & 24 & 404 & 47 \\
\hline 102 & 32 & 258 & 46 & 405 & 39 \\
\hline 103 & 16 & 267 & 20 & 409 & 41 \\
\hline 112 & 33 & 273 & 13 & 410 & 39 \\
\hline 117 & 57 & 285 & 26,28 & & \\
\hline 128 & 10 & 286 & 25 & & \\
\hline 130 & 33 & 300 & 51 & & \\
\hline 138 & 10 & 303 & 51 & . & \\
\hline 148 & 34 & 308 & 52 & & \\
\hline 149 & 34 & 311 & 4 & & \\
\hline 158 & 7 & .319 & 52 & & \\
\hline 159 & 7 & 325 & 53 & & \\
\hline 161 & 35 & 337 & 54 & & \\
\hline
\end{tabular}


Abstract

This report consists of a group of summaries of operating experiences at coal conversion pilot plants, materials evaluation reports, and diagnostic failure analysis reports dealing with the use of Incoloy 800 in coal conversion processes. The Incoloy 800 summaries are categorized into subgroups of spectfic components: auxiliary process equipment, piping, pressure vessels, thermocouples, valves and material evaluation. Each component subgroup is sorted by coal conversion process (such as $\mathrm{CO}_{2}$, Hygas, Synthene, etc.) in alphabetical order and each process is sorted by the date of the report from the earliest to the latest.

If further information is needed on any summary in this report, please contact the Failure Prevention Information Center and refer to the Information Number (I.N:) located at the top of each summary.

\section{Acknowledgement}

The authors wish to thank Mrs. Shirley Harrington, ADP Operations Division, Department of Commerce and Mrs. Dianna Mills and Miss Judy Bolden, Metallurgy Division, National Bureau of Standards for their help in preparing this report. 
AUXILIARY

PROCESS

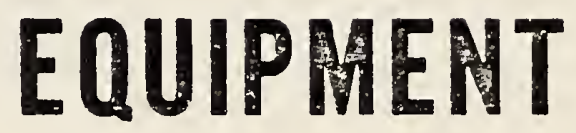




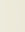

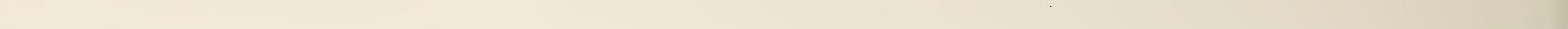
. .

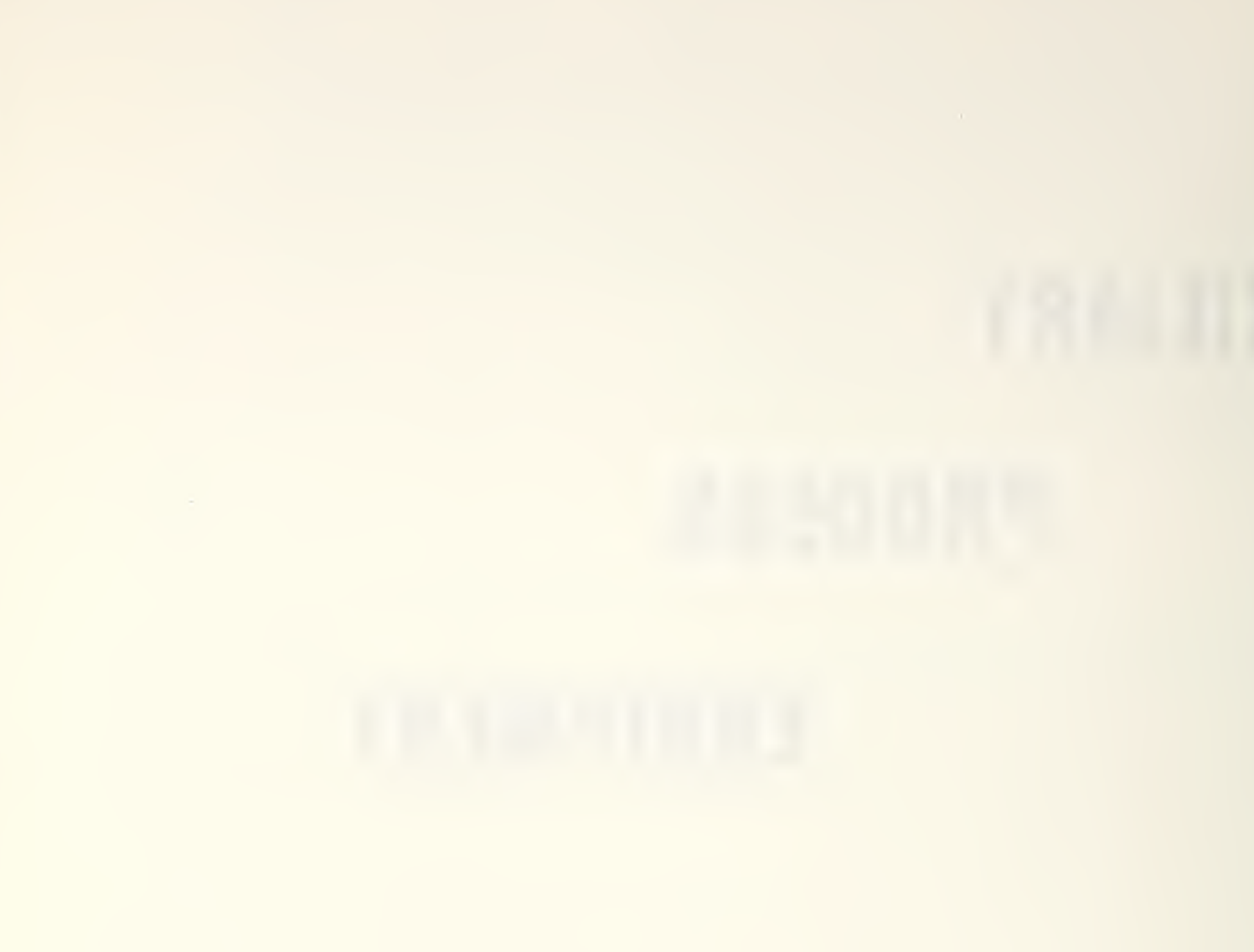


I.N.

1.3
PROCESS

HYGAS
SEARCH CPITERIA

AUXILIARY PROCESS EOUIPMENT

FAILURE ANALYSIS REPIPT, 11/30/73,FROH M.HONES, IITRI, TD F.SCHIRA, IGT . METALLOGRAPHIC EXAMINATION OF FIVE SAMPLES FRDM THE HYGAS PLANT

\section{SUMMARY}

1. SLUPRY DRYER GRID: INCDLOY 800.SERVICE LIFE DF 6 MONTHS. ENVIRONMENT. LIGNITE BED AT 600 F FLUIDIZED WITH A GAS(CONTAINS 1\% HZS) AT 1LCO F AND 1000 PSI.FAILURE GCCURPED BY CORROSION AT SCREW THREADS.RECOMMEND COATING AND REDESIGN TO. ELIMINATE SCREW THREADS.

2. WELDED $4 \times 3$ IN REDUCE?: 446 S.S. SEPVICE LIFE DF 6 MONTHS.ENVIRENMFNT, $1500 \mathrm{~F} A T 25$ PSI, FLUIDIZED LIGNITE-INTERNAL,NITRDGEN-EXTFRNAL.FAILURE CAUSED BY CRACK THAT STARTED IN THE WELD BETWEEN THE PIPE AND FLANGE AND PROPAGATED IN BOTH DIRECTIONS.REASON BEING MATERIAL EMBRITTLEMENT AND RESICUAL STRESSES ORECOMMEVD STRESS RELIEVING.

3. BELLONS: INCOLOY 800 (20 GAUGE).SEPVICE LIFE OF 9 MONTHS.ENVIRONMFNT. $1650 \mathrm{~F}$ IN A CORROSIVE ATHOSPHERE.FAILURE CCCUR?ED BY COMBINATINN OF SURFACE DXIDATION AND INTERGRANULAP ATTACK.RECOMMEND REDESIGN.

4. REFOR.AER DUENCH DDT SHELL: INCOLOY 800. SERVICE LIFE DF 6 MONTHS.ENVIRONMENT, 1650 F AT 100 PSI.FAILIJRE DUE TO THEPMAL FATIGUE CAUSED BY FLUCTUATING TEMPERATURE CTNDITIDNS - RT:COMHEND REDESIGN.

5. BUTTERFLY VALVE: 446 S.S. SEPVICE LIFE DF 2 YEARS.ENVIPANHANT. $1400 \mathrm{~F}$. FAILURE DUE TO INTERNAL CJRROSION AND RESIDUAL STRESSES.RECTHMEND STRESS RELIEVING. 


$\begin{array}{lll}\text { I.N. } & \text { PROCESS } & \text { SEARCH CRITERIA } \\ 311 & \text { SYNTHANE } & \text { AUXILIARY PROCESS EOUIPMENT }\end{array}$

ERDA MAT. AND COMO .FAIL. REPCRT, 8/12/76,FROM J.JEWELL,LUMMUS. INTERMEDIATE HEAD DC-202

SUMMARY

FAILURE: HEAD BUCKLED INTT REVERSE DISH. SERVICE LIFE: UNKNOWN

ENVIRONMENT: $\triangle M B I E N T, C O 2$ GAS,CPEN TO $\triangle I R$.MAX.PRESS. 80 PSIG. MATER IALS: HEAD-3LI S.S .. CONE AND PIPES-INCOLOY 800.

CAUSE: ALLOWABLE DIFFER ENTIAL PRESSURE WAS EXCEEDED.

ACTION: FAILURE ANALYSIS TO BE PERFORMEO BY LUMMUS CO. 
LETTER REPIRT, 4/27/77,FROM T.COX TO J.BATCHELOR, ERDA. REVIEW OF MATERIALS CF CONSTRUCTION FOR SYNTHOIL POU

\section{SUMMARY}

EXPERTS FROM ORNL, ANL, NBS, AND THE MATERIALS BRANCH OF MER HAVE EXAMINED CERTAIN CRITICAL AREAS CF THE SYNTHOIL POU. GENERAL CONSENSUS IS THAT THE MATERIAL SELECTION IS RUITE GDDD. SOME TROUBLE SPOTS ARE PINPIINTED.

$$
\text { PQTENTIAL PROSLEM AREAS }
$$

1. FROM THE EXPERIENCE LT THE SRC PILOT PLANT, CASINGS AVD IMDELLERS IN THE CENTRIFUGAL PUIPS WILL RAPIDLY DETERIDRATE. DESIGN OF THESE PUMPS SHCULD BE REVIEWED.

2. HIGH PRESSURE HYDROGEN LINES: UNTIL THE SAFETY OF CARBON STEEL TUBING CAN BE ESTABLISHED BY APPRDPRIATE TESTS, THESE LINES SHOULD BE CONSTRUCTED DF $304 \mathrm{~L}$ S.S.

3. "HAIRDIN" HEAT EXCHANGERS: POORLY DESIGNED FROM AN ERTSION ANO FABRICATION VIEWPOINT.

4. REACTDR FEED HEATEZ PIPING: INLET PIPING DESIGN COULO LEAD TO EROSION! FROM TURBULENT FLOH INDUCEO BY HYDROGEN.

5. MESH SCREENS: CONTAIN CATALYSTS IN REACTOR FEED SURGE VESSEL $\triangle N D$ THE REACTORS. THEY SEEM TO BE VUL.NERABLE TO EROSIVE WEAR.DESIGN SHMULD BE CHANGED TO ALLOW EASY REPLACEMENT. 
I.N.

191
PROCESS

WESTINGHOUSE
SEARCH CRITERIA

AUXILIARY PROCESS EQUIPMEVT

SCIENTIFIC PAPER, II/25/75, BY L.ALBSRTIN AND J.CUNNINGHAM,WESTINGHOUSE AND S.TENDULKAR. AND P.CHERISH, ENERGY SYSTEMS.

HATERIAL PRCBLEMS IN A SYMTHESIS GAS GENERATOR FOR A MULTI-STAGE CJAL

GASIFICATION SYSTEM

\section{SUMMARY}

GOOO PROCESS DESCRIPTIDN OF THE WESTINGHIUSE COAL GASIFICATION SYSTEM. FAILURES:

1. NOZZLE PLATE AND NOZZLE EXPERIENCED A SEVERE FORM OF HIGH TEMP. CORROSION BY CARBURIZATION AND OXIDATIDN DUE TO EXCESSIVE TEMP. AND ALTSRNATING REDUCING-OXIDIZING ENIVIRONMENTS.

2. MELTING OF SHROUD MATERIAL WAS RESULT OF LOCAL OVERHEATING CAIJSED BY CRACKING OF THE NOZZLE PLATE-DILOT INLET HOUSING WELD, PROBABLE MALFUNCTION OF SEVERAL NOZZLES, AND ACCUMULATION OF HEAVY CARBON DEPCSITS AHEAD OF THE BURNERS.

3. CRACKING IN THE SYNTHESIS GAS GENEPATOR WAS RESULT OF EMBRITTLEMENT DUE TO EXCESSIVE CARBIDE PRECIPITATION ANO THERMAL STRESSES EXPERIENCED DURING CYCLING.

RECOIAMENDATIONS:

1. REDESIGN BURNER SECTICN OF THE GENERATOR SO THAT HIGH TEMP. OF OPERATION CAN BE AVOIDED.

2. USE INCONEL 601 WHICH HAS GOOD RFSISTANCE TO CARBURIZATION AND OXIDATION.

3. EXPLORE THE USE DF REFRACTCRY MATEPIALS AND WATER COOLING DF BURNER CDMPONENTS TO PREVENT FUTURE GAS GENERATOR FAILURES.

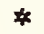


MATERIAL EVALUATION 


I.N.
PROCESS
SEARCH CRITERIA
158
CARBONATE
MATERIAL EVALUATION

LETTER REPORT FROM E.HOXIE TO R.SARRAF, ATOMICS INTERNATIONAL, 6/11/75. CORROSION TEST SPOOL-6376

\section{SUMMARY}

CORROSION TEST SPOOL -6376 .

THELVE ALLOYS WERE TESTEO FOR CORROSION RES ISTANCE UNDER THE FILLOWING CONDITIONS:

PROCESS UIVIT: 3 GALLON RETIRT AT 12 O PSIG

CORROSIVE MECIA: CMAL GASIFICATION PROCESS QUENCH TANK LIQUTR

AVERAGE TEMPERATURE: $35 \% \mathrm{~F}$

AERATION: NONE

AGITATION: NONE

LENGTH OF TEST: 9.5 DAYS

INCONEL $\triangle L L O Y$ 6OO WAS THE MTST RESISTANT ALLCY TESTED BOTH IN REGAPDS TO GENERAL CORROSION RESISTANCE ANO R.ESISTARLF TO STRESS CORROSI IN CRACKING. REMARKS: NO AGITATICN I'I TEST VESSEL.CONSIDERABLE AGITATION WILL BE EXPERIENCED IN SERVICE.SEE I.N. 159 FOR AODITIONAL TESTS.

*

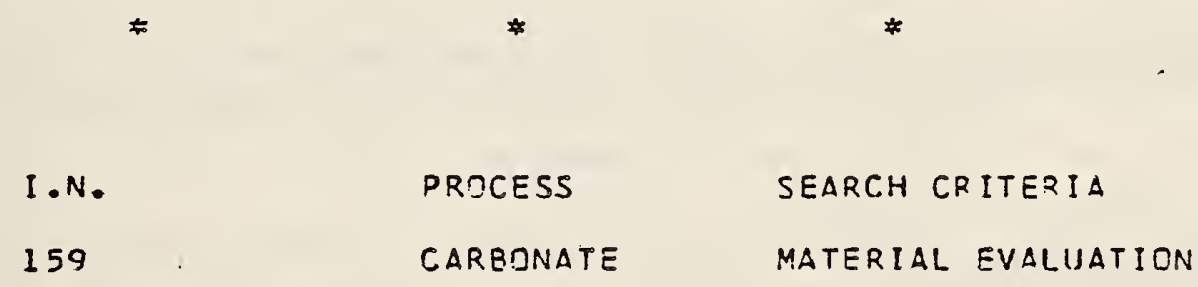

LETTER REPCRT FROM E.HOXIS TO R. SARRAF,ATOMICS INTERNATIONAL,7/11/75. CORROSIDN TEST SPOOL-6375

SUMMARY

CORROSION TEST SPOOL-6375. SECOND GR IUP IF 12 ALLOYS WAS TESTED FOR CORROSIDV RESISTANCE UNDER THE FOLLOHING CONDITIONS. PRDCESS UNIT: 3 GALLCN RETIRT AT 120 PSIG. CORRCSIVE MEOIA: COAL GASIFICATION PROCESS DUENCH TANK LIQUNR. AVERAGE TEMPERATURE: $350 \mathrm{~F}$

AERATION: NONE

AGITATION: NONE

LENGTH OF TEST: 29.5 DAYS

THE DATA CONFIRM RESULTS FROM PREVIOUS TEST.SEE I.N. 158 FDR DETAILS. INCDNEL 600 RECOMMENDED FTR USE AS A CONSTRUCTIINN MATERIAL. 


$\begin{array}{lll}\text { I.N. } & \text { PROCESS } & \text { SEARCH CRITERIA } \\ 128 & \text { CARBONATE } & \text { MATERIAL EVALUATINN }\end{array}$

TEST REPIRT BY J.G.BRUCE, ATJMICS INTERNATIDNAL,7/23/75. CORROSION TESTS OF MATERIALS IN HIGH TEMPERATURE MCLTEN SALT

\section{SUMMARY}

22 MATERIALS WEPE CORROSION TESTEO IN STATIC, I9OOF. MOLTEN STOIUM CARBONATE (FROM THE OCR COAL GASIFICATION PROGRAM) FOR 100 HRS. THE CFRAMICS AL2J3, ZRO2, MGO, AND BEO AND THE METALS PLATINUM AND UNILOY 50491 WERE FOUND TO $8 E$ THE MOST CORRDSION R.ESISTANT MATERIALS.

*

I.N.

138
PROCESS

CARBONATE
SEARCH CRITERIA

MATERIAL EVALUATION

REPORT, 1O/1/75,BY R.SARRAF, ATOHICS INTERNATIONAL.CORROSION TESTING OF CONSTRUCTION HATERIALS IN AI COAL GASIFICATIDN PROCESS OUENCH TANK LIQUOR.

\section{SUMMARY}

CORROSION TESTING DF CONSTRUCTION MATERIAL IN AI COAL GASIFICATION PROCESS QUENCH TANK LIQUTR.

CORROSION TESTS OF UP TO O DAYS EXPOSURE. MATEPIALS TESTED INCLUNED METALS ANO PLASTICS AT $350 \mathrm{~F}$ ANO $175 \mathrm{~F}$ IN STRESSED ANO UNSTPESSED CONDITION.. QUENCH TANK CONDITIONS ARE SHOWN TO PRODUCE SCC TO SUSCEPTIBLE MATERIALS, AND A GROUP OF SUITABLE MATERIALS ARE INDICATED. FIBREGLASS REINFOPCED PLASTICS ARE ALSO SHOWN TO HAVE LIYITED USEFULNESS.

1. FOR HANDLING DUENCH TANK LIRUDR AT $350 \mathrm{~F}$, PRSSS. TO L20 PSIG.THE FOLLOWING ALLOYS HAD LOW CORROSION PATES: INCONEI. 600, 601, 617, RA330. RA333.

2. FOR THE OIJENCH/REGENEQATDR TANK USE ABOVE MATERIALS.

3. PRELIMINARY RESULTS ON PLASTICS TFSTED INOICATE SUITABILITY EF CEVEOAL MATERIALS AT GREEN LIQUDR TEIPERATUPES TD 200-250 F. 
I.N.

182
PRICESS

CLEAN COKE
SEARCH CRITERIA

MATERIAL EVALUATION

INTERIM REPCRT, 3/72-4/74,FROM USS ENGINEERS ANO CONSULTANTS, INC. T? OCR. CLEAN COKE PROJECT

SUMMARY

3-IN CARBONIZER: SECTIONED FIR TBSERVATIDN AFTER 60 HRS SERVICE AT TEMP. OVER $1000 F$ INCLUDING 24 HRS DVER 13OOF. EXAM. SHOWED SIGNIFICANT CARBURIZATION (CABIDES TF CR E IRIN) AT THE SURFACE OF THE $316 \mathrm{S.S.} \mathrm{SHELL.}$ IN AREAS WHERE THE HIT SURFACE WAS IN CONTACT WITH HZS FREE FLUIDIZING GAS. THIUGH IT APPSAPED TE BE STRONG AT HIGH TEMP.. THE CARBURIZEO STEEL HAS EXTPEIAELY BRITTLE WHEN CODL. DEOTH OF CARMUPIZATION (20-25 MILS) WAS GREATEST FRDM TIHF BOTTOY GAS INLET PIPE TO 1 BOUT THE TIP DF THE FLUID BED SECTIIN. ABRVE THIS POINT CARBURIZATION DECPEASED RAPIDLY TO ZERO NEAR THE TOP OF THE DEFNTRAINMENT SECTION. CARBURIZATION IS ATTRIBUTED TO THE AESENCE OF H2S IN THOSE ARFAS WHERE IT TCCURPED. A CONTRILLED CONCENTRATION OF H2S WILL BE MAINTAINFD IN THE RECYCLE FLUIDIZING GAS TO MINIMIZE CARBUPIZATION. SOHE THIN WALL 316 S.5. PIDING HAS BEEN REPLACEO WITH HEAVIER WALL INCOLOY 800.

CORROSION TESTS UNDER CARBQNIZATION CONDITIDNS: 4 SERIES JF TESTS WER = RUN USING $304 \mathrm{~S} .5 ., 316 \mathrm{S.S.,} \mathrm{INCONEL} \mathrm{600,} \mathrm{INCDLOY} 800,310 \mathrm{5.S}$. AND ALONIZED 316 S.S.

SERYES 1. 1370 F, PRESS. 125 PSIA, HZS CONTENT 25-4OPP:A. TEST LENGTH 13.5 HRS. 18 GRAMS OF BLACK DEPOSIT RECTVFRED. SERIES 2. 1250F, 100 PSIA, 50-100 PPM HZS. TEST LENGTH, 92 HRS. NO CARBON.

SERIES 3. SAMF AS 2 EXCFPT 575 GRA:4S OF CHAR PUT INTO REACTIR $\triangle R O U N O$ COUPONS. TEST LENGTH, O5 HRS. RECOVERED CHAR WEIGHED 512 GPAMS WITH NO EVIOENCF OF CARBON OEPOSITION.

SERIES 4. 125OF, 1OO PSIA, NO ADOED HZS AND NO CHAR BED. TEST LENGTH, 95 HRS. HZS CONCENTRATIO.1 WAS 10-20 PPM FROM REACTIONS IN VESSEL. 6 GRAMS OF CARBON DEPRSITS RECOVEREO.

MOST OF CARBON IN TEPOSITS IS IN ELEMENTAL FORM. WHEN THIS IS DEPOSITED ON AN ALLOY SURFATE IT CAN LEAD TO "METAL DUSTING". 304 S.S. SHOWED SOME SVIDENEE OF THIS. CARBURIZATION IS A FUNCTICN TF BDTH HZS CONCENTRATION AND TEMPERATURE. 50-1DO POA OF H2S SHOULD BF $\triangle D E O U A T E$ TO PROTECT INCOLOY 800 FROY CARBURIZATION. 

I.N.
PROCESS
SEARCH CRITERIA
169
CLSAN COKE
MATERIAL EVALUATION

LETTER,6/28/72,FQD* E.PHELPS,CORRDSION! TECHIJOLOGY, TO P.MASCIANTONIO.USS CDRP MATERIALS OF CONSTRUCTION FIR THE CLEAN COKE PROJECT CARBONIZATION PDU

\section{SUSMARY}

AFTER REVIEWING FLOH DI AGRAMS AND PRCCESS CONDITIJNS FDR THE SUBJECT EOIIPMENT THE FOLLONING YATERIALS CF CONSTRUCTION ARE RECOMMENDED.

304 S.S., 316 S.S. .CAQBON STEEL, INCOLOY 820.

SEE TABLES I-IV FJR SPECIFIC R.ECDMHENDATIONS.

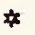

\#

¥

I.N.

PROCESS

SEARCH CRITERIA

183

CLEAN COKE

MATERIAL EVALUATION

QUARTERLY REPIRT,1,2,3/75, FROM USS ENGINEERS AND CONSULTANTS, INC. CLEAN COKE PROJECT

\section{SUMMARY}

CARBONIZATION POU: MAIN RECYCLE-GAS HEATFR. 7 DF 45 ELEMENTS HAD MALFUNCTIONED IE BURNFD NUT., I BRDKEN TERMINAL). FORMATIDN OF EXTENSTVE CARBCN DEPOSITS ON THE HEATER ELEYENTS CAUSED BURNOUT BECAUSE TIF EXCESSIVE TEMPERATURE WITHIN THE CARBON-INSULATEO SHEATHS. NEW HEATER SUBASSEMALY ORDERED WITH IMPRDVED MGS INSULATION AND WIRE ARRANISEHENT TD PEDUCE WATT DENSITY AND SUSCEPTIBILITY TO HEAT DETERIDRATION. DURING A LATER PUUN THE GAS DISTRIBUTIDN PLATF BECAME PLUGGED AND THE WASH OIL RECIRCULATING PUHD FAILED. CAUSES NOT DISCUSSED. PUAO REPLACED WITH A SEALED CRANE CENTRIFUGAL PUMD.

CORROSION STUDIES: COUPONS DE VAPIDUS ALLOYS HERE EXPOSFO I:I SFVER AL LOCATIONS IN THE PDU UNIER ACTUAL DPERATING CONDITIONS (8DOF AND $130 D F$ ). AT LOW TEMPERATURE DNLY CAPBON STEEL SHOWED SIGNIFICANT CORRESION. AT HIGH TEIMPERATURE ALONIIZED INCOLOY SOO HAD A RELATIVELY HIGH CORROSION RATE. PLAIN INCOLOY 820 SHOWED ND SIGNIFICANT CHANGE AFTEQ 244 HRS RF HIGH TEMPERATURE TESTING. TARLES GIVE DETAILS AND RESULTS OF TESTS. 
I.N.

273
PROCESS

CLEAN CDKE
SEARCH CRITEPIA

MATERIAL EVALUSTICN

MONTHLY PPOGRESS REPIRT, $10 / 75$, BY USS ENGINEERS AND CONSULTANTS, INC. CLEAN COKE PROJECT

\section{SUMMARY}

CARBONIZATION PDU: RECYCLE GAS COHPRESSDR.DERSISTENT PROBLEM WITH GAS LEAKS AROUND THE SHAFT.BELIEVFD TO BE CAUSED BY LIGHT FACE LDADING ON THE SEALS. THE REDESIGV INVOLVED CHANGING THE SEAL BALANCE FROM 7OZ TC 1C8\% AND REDUCIVG THE SPRING FDRCE BY ABTUT 20\%. THIS WNULD PROVIDE GREATER FACE PRESSURE TD INSURE A MDRE POSITIVE SEAL. OESIGN HAS PERFRPMED SATISFACTTRILY SINCE INSTALLATION (8/75).

CORROSION TESTS IN CARBONIZATION POU: A COMPLETF SERIES TF TFST SPECIMFNS WERE EXPOSED IN THE PDU DUPIING OPERATION AT FLUIO $8 E 0$ TEMP. TF BOTH BOกF AND $1300 \mathrm{~F}$. IN LON TEMP. EXPOSURE ONLY CARBON STEEL SHAWED SIGNIFICANTT CDRRCSION. IN HIGH TEMP. LOCATIONS NONE OF THE COPROSIDN RATES WERF GREATER THAN 3.O MPY. INCOLOY 3OD SPECIMENS FROM HIGH TEMP.LOCATIONS WFRE EXAMINED METALLOGRAPHICALLY AND SHIWED NO SIGNIFICANT CHANGE IN MICROSTRUCTUPE. TABLES PRESENT PERTINENT DATA FDR THE TESTS.

HYDRJGENATICN PDU: HIGH PRESSURE FITTINGS DEVELDPED LEAKS WHEN TPERATINF, TEHP.REACHED ABTUT TOOF.POSSIBLY RISSULT OF DIFFECENTIAL EXDANSIDN OF DISSIMILAR YETALS(316 S.5.3RDY,410 S.S.GLAND NUT,416 S.S.COLLAR). DESIGN CHANGED TO YAKE ALL PARTS FROM 316 S.S.

$\star$ 
I.N.

PROCESS

180

COED
SEARCH CPITERIA

MATERIAL EVALUATION

REPORT, NO DATE, NO AUTHOP.

MATERIALS TEST PROGRAM-CIED MATERIALS PROGRAM.

\section{SUMMARY}

\section{MATERIALS TEST PROGRAM}

PYROLYSIS VESSELS: TEST COUPONS WERE WELOFO TO THE INSIDE VESSEL WALLS OF THE STAGE TWO PYROLYSIS VESSEL (802F) ANO THE STAGE THPEE PYPDLYSIS VFSSEL (1DODF). TCTAL TEST TIME WAS 4000 HDURS. MATERIALS, COMPOSITICMS. ANO HEAT TREATMENTS OF COUPTNS GIVEN IN TABLE XLVII. STAGE TWO SPECIMENS-GOOD CONOITION VISUALLY. STAGE THREE SPECIMENS-CARBON STEEL CIIJPIMMS HAO EXDERIENI,ED SEVERE ATTACK. TEST SPECIMENS SENT TO LUKENS STSEL FDR. METALLOGRAPHY.

OIL ABSTRBER TDWER: TEST COUDONS WERE INSTALLED IN THE BOTTOM SECTION. TEMPERATURE WAS 600-70OF. TOTAL TEST TIYE WAS 6 MONTHS. INCO ANALYSIS RESULTS GIVEN IN TABLE. TYPES 3DO ANO 4J.J S.S. GAVE SATISFACTORY RESULTS. HYDROTREATING PLANT: TEST CIUPCNIS WERE INSTALLEO ON DIL DISTRIBUTICN PLATE. TEMPERATUPE OF 702-8DCF $\triangle N$ D PRESSURE OF 2000-2500 PSIG. HYDPOGEN CONCENTRATION OF 90-95\%. HZS COMIENTRATIDN OF 2\%. TOTAL TEST TIME OF 2254 HOURS. INCO ANALYSIS.RESULTS GIVEN IN TABLE LII. 
I.N.

PRDCESS

20

CO2

SEARCH CRITERIA

MATERIAL EVALUATION

LETTER REPORT,2/17/7J,FFOM G.CURRAN, CNNSCL,TO C. SCHULZ, CONSOL. HIGH TEMPERATURE ALLOYS FOR CO2

\section{SUMMARY}

MATER IAL EVALUATION DF INT,OLOY 800 AND 310 S.S. IN CALCINER AT LIBRARY, DA. ATMOSPHERE: SULFUR BEARING GAS AT HIGH TEMPERATURES.

\section{$\triangle P P L I C A T I O N S$}

GASIFIER-DEVOLATILIZER INTERNALS: CYCLONES, DIPLEGS, THEPMOWELLS; PRESSURE TAP PRISES, HEATEQS. TEMPEPATURE RANGE 150O-1600F. SULFIUR AS HZS, 0.1\%. 310 S.S. AND IMCOLTY 300 CAN BRTH BE USED.

REGENERATOR INTERNALS: TFMD/PRESS PRDBES, THERMOWELLS. TEMPSRATURE RANISE 1900-1950F. SULFUR A3OUT 0.2\% AS SO2, H2S, S2, COS. NO $\triangle L L O Y$ SUITABL ${ }^{\circ}$. EXTERNAL PROCESS PIPING: HIGH TEMOERATURE HEATERS, SDLIDS TRAMSFER :. INES. TEMPERATURE RANIGE 1500-1950F. SULFUR. FRDM 0-0.1: AS HLS. USE $310 \mathrm{~S} . \mathrm{S}$. OR INCOLOY 800 EQUALLY.

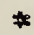

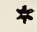

I.N.

22
PRDCESS

$\mathrm{CO} 2$
SEARCH CRITERIA

MATERIAL EVALUATION

LETTER REPIRT,3/4/70,FROM J.LETERLE, CCNCCO,TD M.SHARRAH.

MATERIALS REVIEW COL PILOT PLANT

\section{SUMMARY}

REVISW OF OPERATION AND MATERI

REGENERATOR INTER"IALS: NO SUITABLE MATERIAL AVAILABLE. USE FXPENOABLF METAL T.C. PRTBE OR PERMANENT CERAMIC. WILL EXAMINE BENCH SCALE COMPTNENTS AND EXPOSE COUPONS IN COZ PLANT AND IN LAB.

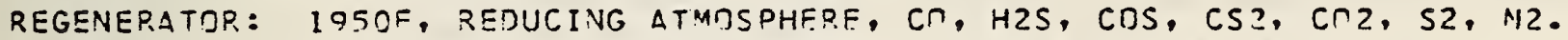
USE REFRACTDRY LINED, NT SUITABLE METAL AVAILABLE. MUST BE QFDUCING (HIGH COI), TO ELIMINATE SLAG FUSION. 310 S.S. BETTER. THAN INCOLOY 800 BUT EMBRITTLES ON CARBUPIZIN!G. SUGGEST ALONIZING FIR T.C.

DOLDMITE RETURN LINES: I9OCF, "INERT"PURGE GAS. NORMALLY DO VOT SEE SULFUR BUT SOIAE LEAKS IN. USE $310 \mathrm{~S}$.S. INSTEAD DF INCRLOY SDO TO REDUCE SULFIDATION. PURGE GAS CDNTAINS 3-4\% CO THAT. WILL CARBURIZE AND EMBRITTLE. 310 S.S. MUST MOD!FY GAS.

COOLING WATER SYSTEYS: USE INHIBITCR (DICHRDMATE) WITH CARBMN STEEL. TO PREVENT SCC-CL OD NOT ALLOW WATER TO STAND IN PIPES ON SHUTDOWN. WELDING: AVOID HIGH NI WELO RODS.

MISC. : BENCH SCALF TESTS SHOW CORROSION DF 310 S.S. AND HASTELLOY $X$ AT 1400 TO 15OOF. NO REASON. 


$\begin{array}{lll}\text { I.N. PROCESS } & \text { SEARCH CRITERIA } \\ 99 & \text { CO2 } & \text { MATERIAL EVALUATION }\end{array}$

REPORT FROM H.CRJNDEP. TC J.LETERLE, PONCA CITY, 5/13/74. BENDING PROPERTIES AND HIGH TEMPERATURE SULFUR CDRROSION RESISTANCE TF ALONIZED INCOLOY 800 .

\section{SUMHARY}

BENDING PROPERTIES AND HIGH TEMPERATURE SULFUR CORROSIDN RESISTANCE DF ALONILED INCOLOY 800 .

CONCLUSIONS

1. THE alonized LAYER ON INCOLDY 300 IS MADE UP OF TWO PARTS, A HARD BRITTLE DUTSIDE LAYER AND A MURE DUCTILE INNER LAYER. THE INNER LAYER PROVIDES THE MDST RELIABLE PROTECTION $\triangle G A I N S T$ CORROSION.

2. AN ANNEALING TREATHENT JF $1830 F$ FOR 24 HRS MAKES THE OUTER ALCNIZED COATING MORE DUCTILE.

3. IN THE ANNEALED CONDITIDN TUBIYG COULO BE BeNT TO a RADIUS OfF 3.75 IN AT 1650F, A RADIUS JF E IN AT L3OZF, TR A PAOIUS OF 26 IN $4 T$ IOOOF.

4. A SOUND ALONIZED LAYER GIVES PROTECTION AGAINST HIGH TEMPERATUP. HZS CORROSION.

5. BENDING, IN EITHER THE ANNEALED CR UNANINEALED CONDITION, TPENS UP CRACKS IN THE CUTER LAYER, THEREBY REDUCING TO SOME DEGREE THE CORETSION RESISTANCE DF THE SURFACE.

6. SENDING IN THE "AS-ALONIZED" CTNDITIOV OR BENDING IN THE ANVEALED CONDITION AT TOD LOW A TEMPERATURE WILL ALSO CRACK THE INNFR LAYFR AND GREATLY REDUCE THE CORROSION RESISTANCE OF THE ALONIZED COATING.

*
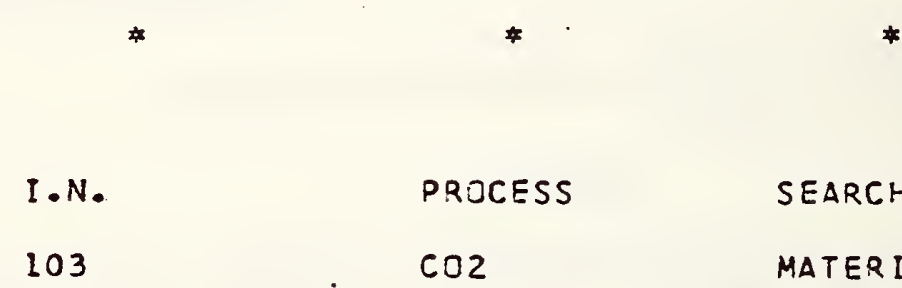

REPORT FRCY S.WDRDEN, PNNCA CITY,TO C.SCHULZ,CDNSOL, 6/13/74. ALONIZED INCOLOY 800 PREHEATER COIL FABRICATION GUIDELINES

\section{SUMMARY}

ALONIZED INCCLOY 800 PREHEATEQ COIL FABRICATION GUIDELINES. SUMMARY OF CONOCD RESEAPCH REPDRT 72-74- L3OL OF THE STUDY MADE TD YIELD GUIDELINES FOR BENDING ALONIZFD TUBING FOR PREHEATER COILS. 
I.N.

56
PROCESS

$\mathrm{CO} 2$
SEARCH CRITERIA

MATERIAL EVALUATION.

REPORT, $10 / 20 / 75,3 Y$ H.CRCWDER, CDNOCD.

CORROSION COUPON EVALUATION. SERIES III.

SUMMARY

EVALUATION OF CORROSION OF SEVERAL ALLOYS IV REGENERATOR GAS. EXPOSURE: SERIES II - 550 HRS, OXIDIZING

$$
\begin{aligned}
& 650 \text { HRS, REDUCING } \\
\text { SERIES III - } & 500 \text { HRS, } \\
& 620 \text { HRS, OXIDIZING }
\end{aligned}
$$

VERY DETAILED METALLOGRAPHIC ANALYSIS. CDRROSION RATES 10-360 :1PY. ALLOYS TESTED: S.S.- 309, 310, 329. HAYNES - 40, 150,706, 718 . INCONEL - 706, 718, 793. INCOLOY - 800, 801.

17 


$\begin{array}{lll}\text { IN. } & \text { PROCESS } & \text { SEARCH CRITERIA } \\ 366 & \text { PC } & \text { MATERIAL EVALUATION }\end{array}$

REPORT, ND., BY J.DEVAN, P.COOPER, IS. HARE IS, ORAL.

MATERIAL EVALUATIIN-HEAT EXCHANGER TUBES

SUMMARY

MATERIAL SELECTION FOR HEAT EXCHANGER TUBES IN A MODULAR INTEGRATED UTILITY SYSTEM

TEST PROGRAM: SURVEILLANCE COUPONS OF 310 AND $316 \mathrm{~S} .5$. INCOLOY 800 AND 325

WERE EXPOSED IN COMBUSTION POWER COMPANY'S NOEL FLUIDIZED BED REACTOR.

TEST CONDITIONS: TEMP. 16OG-1700 F, SEVERAL HUNDRED PERCENT EXCESS AIR. NO CODLING TUBES IN RED. DOLOMITE ADDED TO TIE UP SOL AND A GEORGIA CLAY

ADDED AS A CORROSION INHIBITOR. SPECIMENS LOCATED IN THE FREE BOARD POSITION JUST ABoVE THE FLUID RED. INCDLOY 325 WAS EXPOSED FOR 1000 HRS .310 AND $316 \mathrm{~S} .5$. AND INCOLOY 800 HERE EXPOSED FOG 500 HRS AND $10 C$ O HRS.

RESULTS: SIGNIFICANT INTERIGRANULAR OXIDATION OCCURRED ON ALL FOUR MATERIALS. SCALE WAS THICKEST ON $316 \mathrm{~S} .5$. NO INDICATION OF SULFIDATION OR CARBIIP. IZATIOV. ANALYSIS OF DATA WILL CONTINUE.

FUTURE: CONTROLLED EXPERIMENTS DUPLICATING THE CONDITIONS EXPECTED IN THE MISS SYSTEM ARE NEEDED TO ASSESS COMPATIBILITY PROBLEMS.

18 

I.N.
PROCESS
SEARCH CRITERIA
1
HYGAS
MATERIAL EVALUATION

LETTER, 4/2/75,FRCY A.MAC NAB,C.F.BRAUN, TO P.TARMAN, IGT. MATERIAL SELECTION FDR HYGAS STEAMIIOON GASIFICATIDN PILOT PLANT

\section{SUMMARY}

DISCUSSION DF MATERIALS TO RESIST SULFIDATION IN PIPING TO THE REACTZR AND SECOND STAGE REDUCER SPARGE RING.ATMOSPHERE WILL BE REDUCIYIG GAS CONTAINING 0.1 MOLE PERCENT HZS AT 2OOOF. INCOLOY 800 NND $310 \mathrm{~S} .5$. WILL NOT HOLD UP. RECOMYEND 5OCR-5DVIIASTM A560 OR UNILOY 5O/5OI OR ALONIZED $31 ?$ S.S. CR ALONIZED INCOLOY $3 C 0.5 O C R-5 O N I$ HAS GOND SULFIDATIDN RESISTAVCS BUT POOR HIGH TEMP. STRENGTH.RSCDMMEND USE TF THIS MATERIAL AS CLADOING TO A SUBSTRATE DF INCOLOY 800 OR $310 \mathrm{~S} . \mathrm{S}$.

*

$\begin{array}{lll} & * & * \\ \text { I.N. } & \text { PROCESS } & \\ 79 & \text { SEARCH CRITERIA }\end{array}$

LETTER, 6/2/75, FRDM P.TARMAN, IGT,TO A.MAC NAB,C.F.BRAUN. MEMO, 5/30/75,FR.OY R.SACHTA TO P.TARMAN,IGT. FEASIBILITY AND AVAILABILITY OF INCOCLAD $671 / 800 \mathrm{H}$ PIPE

SUMMARY

TARMAY CDMMENTS ON MAC NAB'S SUGGESTION DF USING 5OCR-5ONI AS CLAODING ON INCOLOY 800 A.VD HIS RECOMYEVDATION THAT IGT CONTACT HUNTINGTON $\triangle L L O Y S$ FIR INFDRMATION.

MEMO FROM BACHTA GIVES INFIRMATICV FRGM HUNTINGTON ALLOYS.DRTBLEHS IN GETTINT THIS MATERIAL WDILO BE WSIZE, BIGGEST PQTOUCFD BY HUNT INGTCN IS 2-1/2"OD, IGT NEEDS 4" OD. 2I CLADDING THE INTERIOR DF THE PIPE.MOST PROQUUTS CLAD ON OUTSIDE ONLY.

INCOCLAJ 671/800H PIPE HAS AN INCOLOY 800 SUBSTRATE WHICH PQDVIDES STREAIGTH AT HIGH TEMPERATURES ANO INCONEL 67 I (APPROX.5OCR-5ONI) CLAODING WHICH PROVIDES RESISTANCE TO SULFIDATION. 


$\begin{array}{lll}\text { I.N. PROCESS } & \text { SEARCH CRITERIA } \\ 26 & \text { SRC } & \text { MATERIAL EVALUATIION }\end{array}$

LETTER, 3/18/74,FROM A.HENKE, GULF RED,TO B.SCHYID, SRC. MATERIALS MCNITJRIVG PRCGRAM FOR SRC PRTCESS

LETTER REPORT, $1 / 30 / 74$, FO NM J.MCCOY, GULF $2 E D, T C$ 8.SCHMID, SR.C. CORROSIONIEROSIDN MONITCRING PROGRAM AT SRC

\section{SUMMARY}

ESTABLISHMENT OF A CORROSION/ERDSION MATERIALS MONITORING PROGRAM AT SRC PLANT. PROGRAM CINSISTS JF:

1. ULTRASONIC TESTING TO DETERMINE THICKNESS AT KEY POINITS IN THE FQUIPMENT.

2. VISUAL INSPECTION.

3. EVALUATION OF TFST COUPONS OF: 31 I S.S., 321 S.S., 304 S.S., MONFL, INCOLOY 800. CARBON STEEL, STELLITES. COLMONOY, TUNGSTEN CARBIDE, 321 S.S. (ALUMINIZED).

\begin{tabular}{lll}
$*$ & \multicolumn{1}{c}{$*$} & $*$ \\
& & \\
I.N. & PRCCESS & SEARCH CRITERIA \\
267 & SRC & MATERIAL EVALUITICN
\end{tabular}

REPORT, 5/28/76,FRDY D.CANFIELD TD L.SAMIJSLS,FT.LEHIS.

FAILURE AND REPAIR CF THE WASH SCLVENT COLUMN

SUMMARY

FAILURE RFPORT: THE SHELL DF TH= 3/3" CARBDN STEEL (SA-515 GR. 55) COLIUYN STARTED TO LEAK BETWEEN THE 18TH AND 1OTH TRAYS. ATTEMDTS TT PATCH THE HOLE FAILED. THE TRAYS WERE REMDVED AND THE COLUMN WAS INSPECTED WITH THE FOLLOWING RESULTS. II MEARLY ALL THE TRAY SUPPDRT RINGS AND DOWNCOMFR SUPPORTS FRDM TPAYS 12-2I YSEPE ALMEST COMPLETELY CORRODED, 2) AREAS OF LIQUID PHASE CONTACT INERE CORRGDED HORE THAN THOSE IV CONTACT WITH VAPJR PHASE, 3) 14 GAUGE 334 S.S. TFAYS HAD LDST ABOUT 7 MILS, 41 THE 16 AND 20 GAUGE $304 \mathrm{~S} . \mathrm{S}$. VALVES WERE THINNIVG AT CLIP ENDS, 5) THERE APPEARED TO RE NO CORROSION PRODUCTS PQESENT.

FAILURE ANALYSIS: THE CORROSION $\triangle P P E A R S$ TO BE SIMILAR TO NAPTHENIC $\triangle C$ ID CORROSION AS DESCRIBED IN METALS HANDROOK, VCL. L. HOWEVER, NO DEFINITE CONCLUSIONS ARE MADE.

REPAIRS: THE TOP 13-FT SECTIDN CF THE 32-IN CO COLUMN WAS REPLACED USING 1/4-IN 316L S.S. THE TRAYS AND DOWNCRMER SUPPIRTS WERF DEPLACFD WITH $316 L$ S.S. VEW $316 \mathrm{~S} . \mathrm{S}$. TRAY VALVES WERE INSTALLED.

CORROSION TEST RESULTS: CCRRDSIOV RACKS NERE INSTALLEO IN WASH SOLVENT COLUIAN TO EVALUATE MATERIALS. TYOE $321 \mathrm{~L}$.S. ANJ INCOLOY BOD SHOWED VERY GODD RESISTANCE TO THE COPRCSIVE ENVIRONMENT. MOLY BEARIVG ALLOYS (2-3\%) ARE THDUGHT TO HAVE GGDO CORRISION RESISTANCE TO PSAPTHENIC ACIO CORROSINN. SEE I.N. .3C2 FIR FURTHER INFORMATION. 
PIPING 

I.N.

13
PROCESS

HYGAS
SEARCH CR ITERIA

BELLDWS

FAILURE ANALYSIS REPIRT, $11 / 30 / 73$, FRIM M.HOWES, IITRI, TD F.SCHORA, IGT. METALLOGRAPHIC EXAMINATION DF FIVE SAMPLES FROM THE HYGAS PLANT

\section{SUMMARY}

1. SLURRY ORYER GRID: INCDLOY 800. SERVICE LIFE OF 6 MONTHS.ENVIRCNMENT, LIGNITE BED AT 6OO F FLUIOIZED WITH A GASICONTAINS $1 \%$ HZSI $\triangle T$ TLC? F AND 1000 PSI.FAILUPE OCCIIRRED BY CORROSION AT SCREW THREAOS.RECOMMFNI COATING AVD REDESIGV TO ELIMINATE SCREW THREADS.

2. WELOED $4 \times 3$ IN REDUCE?: 446 S.S. SERVICF LIFE OF 6 MONTHS. ENVIRON!AFNT, 1500. F AT 25 PSI, FLUIDIZED LIGNITE-INTERNAL, NITROGEN-EXTERNAL . FA ILURE CAUSED BY CRACR. THAT STARTED IN THE WELD BETWEEN THE PIPE 1 ND FL ANGE ANO PROPAGATED IN BOTH DIOECTIONS.REASCN BEING MATERIAL EMBFITTLFMEVT $\triangle N D$ RESICUAL STRESSES.RECQMMEND STRESS RELIEVING.

3. BELLOWS: INC TLOY 80 ) ( 20 GAUGE). SEP.VICE LIFE DF 9 MONTHS. EIIVIRONMFMT. $1650 \mathrm{~F}$ IN A CORRTSIVE ATHOSPHER . FA ILURE OCCURQED BY COMBINATION OF SURFACE OXIDATION AND INTERGRANULAR ATTACK .RECOM:AEND REDESIGN.

4. REFORMER QUENCH POT SHELL: INCOLOY 800.SERVICE LIFE OF 6 YONTHS. ENVI IONMEVT, $1650 \mathrm{~F}$ AT 102 PSI.FAILURE DUE T? THEQMAL FATIGUF CAUSED BY FLUCTUATING TEMPEPATURE CONDITIONS RECOMYEND REDESIGN.

5. BUTTEQFLY VALVE: 446 S.S. SFRVICE LIFE OF 2 YEARS. ENVIRGMYENT, $1400 \mathrm{~F}$. FAILURE DUE TO INTEDNAL CDRRDSIDN AND RESIDUAL STRESSES.EECOMMIEND STRESS RELIEVIYG.

*

\begin{tabular}{lll} 
& \multicolumn{1}{c}{$*$} \\
& & \\
I.N. & PROCESS & \\
213 & HYGAS & SEARCH CRITERIA
\end{tabular}

TELECON, 4/13/76, FROM S.GREFNBERG, ANL, TO B.ORCHARO, IGT. THERMOCOUPLE PROTECTION TUBES, PRESS. TAP TUBES, GASIFIER TRANSFER LINE BELLDWS.

\section{SUMMARY}

THERY. PROTECTION TUBES:TUBES TC-23 AND TC-5 IDENTIFIED AS INCOLLY 800. PRESSURE TAP TUAES:SCALE REMDVED FROM OUTER SUPFACE CONTAINED 14.4\% $S$. EXPANSICN JOINT BELLOWS:CTAL PRODUCT REMOVED FRTM BELLOWS HAS $\triangle$ SULFUR CONTENT OF APPROX. 3\%,VEPY CLOSE TO THAT DF FEED MATERIAL. THESE RESULTS TFNI TO CONFIP.Y VIEW THAT TUSES FAILED AS A RESULT OF SULFUR ATTACK. HETALLOGRAPHIC EXAH. IS IN PROGRESS. 
I.N.

236
PROCESS

HYGAS
SEARCH CRITERIA

BELLOWS

TELECDN, 4/27/76,FROM S.GREENBFRG, ANL, TO B.ORCHARD, IGT. EXPANSION JOINT-GASIFIER TRANSFER LINE.

\section{SUMMARY}

SEM ANO OPTICAL EXAM. PEVEALED PITS DN INTERIOR AND EXTERIOR SURFACES IN THE VICINITY OF CQMPLETE PERFDRATIONS BUT NOT IN AREAS OF APPARENTLY SOUND METAL. $X$-RAY ANALYSIS ESTABLISHEO THE PRESENCE OF METAL-COAL REACTION PRONUCTS IN CLOSE PROXIMITY TI THE FDGE OF A PERFORATIOR. IT WILL BE SSTARLISHED HHETHER THIS IS UVIQUE TO PERFERATED AREAS OR HAS BRTAD OISTRIBUTION.

BELLOWS FAILURE RESULTING FROM INITIAL DEFECTS(MANUFACTUPING) MUST ALSO BE CDNSIDERED.

SEE I.N. $186,194,210,274,295,286$ FIR FURTHER INFIRMATION.

\#

\begin{tabular}{lll} 
& \multicolumn{1}{c}{$*$} & \\
& & \\
I.N. & PROCESS & SEARCH CRITERIA \\
210 & HYGAS & BELLOWS
\end{tabular}

TELECON, 5/5/76,FRTM S.GREENBERG, ANL, TO 3.ORCHAPD, IGT . EXPANSION JCINT-GASIFIER TRANSFEQ LINE.

SUMMARY

COAL PRODUCT-METAL REACTION PRODUCTS ARE FIUND GENERALLY DN BDTH SIDES OF THE BELLOWS AND IN ALL AREAS.IT SEEMS UNLIKELY THAT CORROSION IS THE MAIV CAUSE OF BELLOWS DERFCRATICNS.

CURPENT VIEHS ARE THAT THE PITS ARE DUE TO EROSICN.AT LEAST IN THE CASE OF INTERNAL SUPFACE PITS.PITTING WAS PRECFDED BY LOCALIZED FAILURE TF THE LINEP. TUBE ALLOWING PAPTICAL IMP INGEYENT DN THE INTER ICR BELLGNS SURFACE. AFTER PERFORATIMN OF THE BELLOWS THE STRUCTURE OF THE TRANSFER LINE ASSEMBLY ALLOWED PARTICLE IMPINGEMENT ON THE EXTERIDR SURFACE DF THE BELLOWS.

IT IS IMPORTANT TO EXAMINE THE REMAINOER DF THE BELLOWS ANO ESDECIALLY THE LINER TUBE.

SEE I.N. 186,194,236,274,285,286 FJR FURTHER INFIRMATION. 
EROA MAT. AND COMP .FAIL.REPORT, 5/7/76,FROM H.ORCHARO, IGT. 3. EXPANSION JOINT FROM LINE 322

\section{SUMMARY}

FAILURE: TWO LEAKS IN BELLOWS-LARGE LONGITUDINAL ANO CIRCUMFERFNTIAL CPACKS IN SHORT NIPPLE.

SERVICE LIFE: $\triangle P P R C X .2$ YRS INTERMITTENT SERVICE.

MATERIAL: INCOLOY 802

PRIOR REPAIRS: ENO NIPPLES CHANGED FROM TP446 TO INCOLOY $8 O O$ PRIOR TI INSTALLATION.

ENVIRONMENT: EXTERHAL-N2 AT IZOF. INTERNAL-SYNTHESIS GAS AT $1200 F 1722$ $\mathrm{H} 2 \mathrm{O}$, 9\% $\mathrm{H} 2$, 9\% $\mathrm{CH} 4,4 \% \mathrm{CO}, 3 \% \mathrm{~N} 2$, < I? H25.

COMMENTS: CRACKS IN END NIPDLE APPEAR TO BE LOCATEO AT THE SAME POINT WHERF THE LINER WAS ATTACHED TO THE SND VIPPLE HITH A FILLET WELO.

ACTION: $\triangle N A L Y S I S$ TO BE PERFORMEO BY ANL.

¥

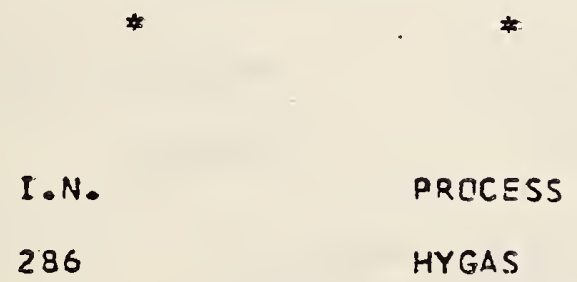

\section{*}

«

286 HYGAS BELLOWS

TELECON, 5/12/76 AND 5/13/76,FROM S. GREENBERG, ANL, TO B.DRCHARO. IGT. EXPANSION JOINT-GASIFIER TRANSFER LINE.

\section{SUMMARY}

MANY HOLES AND PITS DISCOVERED IN INCOLQY 8 OO BELLOWS. DEPISIT ON INNER SURFACE IS MAINLY THE RESULT OF COUNTER-CUQRENT CLEANING OPERATICNS. CORROSION FILY DN EXTERIDR IS RESULT OF CONTAMINATION DF N2 ATMOSPHER BY IN-LEAKAGE OF COAL, PRODUCT GAS, CIL ANO WATER. METALLOGPAPHIC ANALYSIS INOICATES DITTING IUITIATED AT INSIDE SURFACE. WATER CONDFNSATIOM DURIN!G SHUTDOWN MAY BE A. CONTRIBUTING FACTDR. EVIDENCE FOUND OF SULFIOATION AND OVER-TEMPERATURE OPERATIJN (145OF). NORMAL OPERATIVG TEMP. IS IDOOF. MATERIAL RECOMMENDATIONS

1. IF PITTING ATTACK IS CAUSE OF FAILURE, 316 OR $317 \mathrm{~s} .5$. CDULD RE USED (USE INVDLVES RISK DF SCC).

2. IF HIGH TEMP. GASEOUS CORDDSIOV IS ALSO IYPORTANT THEN INCONEL 625 OR HASTELLOY C HOULO BF PREFERARLE (ALSO REDUCE RISK OF SCC). SEE I.N. $186,194,210,236,274,285$ FOR FURTHER INFORMATION. 


$\begin{array}{lll}\text { I.N. } & \text { PROCESS } & \text { SEARCH CRITERIA } \\ 194 & \text { HYGAS } & \text { BELLOWS }\end{array}$

TELECQN,6/2/76,FROM S.GREENBERG, ANL, TO B.BAIR, IGT. EXPANSION JOINT-GASIFIER TRANSFER, LINE.

\section{SUMMARY}

ANALYSIS CF COAL PRODUCT FO:JND IN BELLOWS SHOWED A SOLUSLE CHLTRIDE CONC. OF APPROX.0.2 \%.THUS PITTING CORROSION HYPOTHESIS IS POSSIBLE.

FUTURE GELLOWS HIGHT BE FABRICATED FROM ALLOYS RESISTANT TO PITTIVG CORPOSION 316 DR 317 S.S., INCONEL 625,4ASTELLOY C.HOWEVER, NO EXISTING MATERIAL MIGHT BE SATISFACTORY FDR BOTH $\triangle Q U E N U S$ PITTING CORROSION AS WELL AS HIGH TEMP. SULFIDATION IN TERMS OF A LDNG SERVICE LIFE.

SEE I.N. $186,210,236,274,285,286$ FOR FURTHER INFDRMATION.

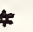

\begin{tabular}{lll} 
& \multicolumn{1}{c}{$*$} & \\
& & \\
I.N. & PRCCESS & SEARCH CRITERIA \\
285 & HYGAS & BELLOWS
\end{tabular}

TELECON,6/15/76, FROM S.GREENBERG, ANL, TO B.DRCHARD, IGT. EXPANSIDN JOINT-GASIFIER TRANSFER LINE AND AAG DIPLEG.

\section{SUMMARY}

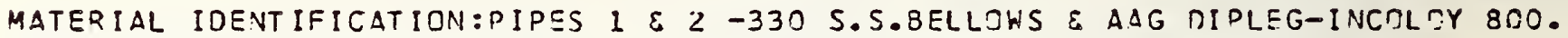
THE HIGHER. SI CONTENT DF 33) S.S. MAKES THIS ALLOY MORE SUSCEPTIBI 5 TO CRACKING OF WELD JJIMTS.RECDMHEND INCOLOY 800 RATHER THAY 330 S.S.DR 18-8 S.S. WELOING RODS BE USED WHEV JOINING 330 S.S. OR 18-8.

STRESSES IMPORTANCE OF MAKING SURE THEY GET MATERIALS THEY SPECIFY AND ALSO THE IMPORTANCE OF CONTROLLING IN-PLANT WELOING PROCEDURES INCLUDING SPECIFYING OF TYPE DF WELD ROD. 


$\begin{array}{lll}\text { I.N. } & \text { PRGCESS } & \text { SEARCH CRITERIA } \\ 220 & \text { HYGAS } & \text { BELLOWS }\end{array}$

ERDA MAT . AND CQMP.FAIL.P.EPORT, 1/20/77,FROM W. ORCHARO,IGT. BELLOWS FAILURE-321 LINE

\section{SUMMARY}

FAILURE: DURING START-UP PRESSUPE TESTING, LEAKING GAS WAS DGSFRVED NEAR THE BOTTOM OF THE BELLOWS. EXACT LDCATIDN COULD NOT BE INDENTIFIFD. SERVICE LIFE: 8 MONTHS INTERMITTENT SERVICE. ENVIRONYENT: EXTERNAL-NZ (ALSO INTERMITTENTLY HYDRAIJLIC OIL. HATER, CT:AL

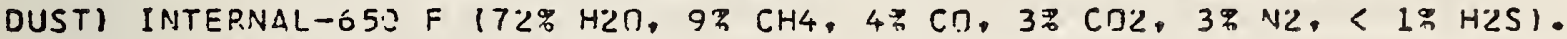
MATERIAL: INCOLOY BOO 20 GAUGE.

CAUSE: EITHER PINHOLE LEAKS IN BELLOWS OR BELLOW SEPARATIJN FROM END PLATE IS THE EXPECTED CAUSE OF FAILURE. ACTION: RETURNED TO MANUFACTURER.

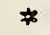


TELECON,6/15/76,FROY S. GEFENBERG, ANL, TO B.ORCHARD, IGT . EXPANSION JOINT-GASIFIER TRANSFSR LINE AND AAG DIPLEG.

\section{SUMMARY}

MATER IAL IDENTIFICATIDN:PIPES 1 \& $2-330$ S.S.BELLOWS \& AAG DIPLEG-INCDLOY 800. THE HIGHER SI CONTENT JF $330 \mathrm{~S}$ S.S. MAKES THIS ALLOY MIRE SUSCEPTIBLE TO CRACKING DF WELD JOINTS.RECOMMEVD INCOLOY 800 RATHER THAV 330 S.S.MR 18-8 S.S. WELOING RODS BE USED WHEN JOINING $330 \mathrm{~S} . \mathrm{S}$. OR $18-9$.

STRESSES IMPORTANCS OF MAKING SURE THEY GET MATERIALS THEY SPECIFY AND ALSO THE IYPDRTANCE DF CONTROLLING IN-PLANT WELDING PROCEDURFS INCLUDING SPECIFYING OF TYPE OF WELD ROD.

$\begin{array}{lll} & * & * \\ \text { I.N. } & \text { PROCESS } & \text { SEARCH CRITEPIA } \\ \text { 344 } & \text { HYGAS } & \text { DIPLEG }\end{array}$

FINAL FAILURE ANALYSIS RFPRQT, 12/76, BY S.DANYLUK \& S.GREENBERG, ANL. HYGAS ASH AGGLOMERATING GASIFIER IVTERNAL CYCLONE OIPLEG FAILURE

\section{SUMMARY}

FAILURE: THE WALL MATERIAL TF THE AAG CYCLONE DIPLFG WAS SEVERELY CORRODED, WHICH RESULTED IN THE DETACHMENT OF THE FLAPPER VALVE. AT THE BOTTOM DF THE DIPLEG.CAR.RURIZATION AND SULFIDATION JF THE OIPLET, HAD OCCURRED WITH THE CORQOSION BEING MORE SEVERE NEAR THE BOTTOY. IN SOME AREAS I/3 OF THE OIPE WALL WAS CONVERTED TO METAL SULFIDES. MOLTEN SLAG WAS PRESENT NEAR THE TOP OF THE DIPLEG,CLOSE TO THE EYCLONE, WHICH INDICATES THIT THE DIPLEG IAS EXPOSFD TO QFF-DESIGNIHIGHI TEMP. ENVIRONMENT: GASIFIER WAS SPERATED WITH BITH STEAM ANO DXYGEN AND THF DIPLEG WAS EXPOSEO TO THIS FOR ABOUT 2030 HPS, 300 HRS DF WHICH WERE IN $A$ LOW STEAM ATMOSPHERE.BED TEMPERATUPE IS 1850-1975F AND THE GAS COMPDSITION $30 \%$ CO2,15\% CC, 15\% H2, 5\% 12 ANN THE BALANCE WATER. MATERIAL DF CONSTRUETION: INCOLOY 300 . CAUSE: THE FAILURE OF THS DIPLEG IS BELIEVED TO RE ASSOCIATED WITH HIGH TEMPSRATURE (OFF-PRDCESS) IJPERATION WHICH LED TO SULFIDATION AND CARBURIZATION.

\section{RECOMMENDATIDNS}

1. PROCESS TEMPERATURES MUST RE KEFT WITHIN THE DESIGN LIMITS FOR INCOLCY $8 O D$.

2. USE OF A HIGHER CHRDMIUM CONTENT STAINLESS STEEL SHOULD ALLEVIATE THE SULFIDATION DRDBLEY.

3. WE CONCUR WITH THE SUIGESTION BY HYGAS PFRSDNNEL TO ALONIZE THE FLAPPER VALVE, WHICH :AAY PROVIDE IMPROVED PERFDRMANCE OF THIS COMOONENT. 


$\begin{array}{lll}\text { I.N. } & \text { PROCESS } & \text { SEARCH CPITERIA } \\ 365 & \text { SYNTHANE } & \text { DIPLEG }\end{array}$

TELECON, 3/31/77,FROM S.DANYLUK, ANL, TO D.OUBIS, SYNTHANE.

BALLOONING OF C-MO STEEL DIPE AND PITTING IN CYCLONE DIPLEG

\section{SUMMARY}

A. BALLOONING OF C-MD STEEL PIPE

1. DESIGN TEMP. AND PRESSURES CDULD NOT PROVIDE SUFFICIENT STRFSS TO PLASTICALLY DEFORM THE PIPE.

2. WALL THICKNESS MEASURFMENTS SEEM REASINABLE.

3. TENSILE TESTS, HARDNESS TESTS, CHEMICAL ANALYSIS AND YETALLOGRAOHIC ANALYSIS HILL BE PERFRRIAED.

4. AT PRESENT CAUSE DF BALLOJNING IS UNKNOWN.

B. CYCLONE DIPLEG-INCDLCY 800

1. CORROSION PITS HAVE DEVELOPSO.

2. SECTIONS OF PIPE ARE TI BE SHIPPED TO ANL.

3. SYNTHANE REOUESTS MLTEPIAL IDENTIFICATION ANO REASON FIR DITTING.

SEE I.N. 356,357 FOR FURTHER INFORMATION ON BALLOCNING DROBLEM. 


$\begin{array}{lll}\text { I.N. } & \text { PROCESS } & \text { SEARCH CRITERIA } \\ 89 & \text { CO2 } & \text { PIPING }\end{array}$

INTEPOFFICE REPORT, $8 / 7 / 72$,FROM H.CROWDER TO J.LETERLE,CONOCO. METALLOGRAPHIC STUDY DF 4-INCH DIAMETER INCOLDY 800 PIPF.

SUMMARY

TWO SAMPLES OF REMAINING DIPEISEE I.N.38) WERE EXAMINED TO DETERMINF SUITABILITY FOR FURTHER USE.

CONCLUSIONS

1. THE INSIDE SURFACE HAS BEEN DAMAGED BY SULFUR CORROSION AND EY GRAIN BOUNOARY PENETRATIEN GY SULFUR.

2. OVERHEATING CAUSED SOYE INCREASF IN GRAIN SIZE.

3. MOST OF THE WALL THICKNESS IS STILL SOUND ENOUGH TJ ALLOW THIS TOP SECTION TO BE USED FOR FURTHER SERVICE.

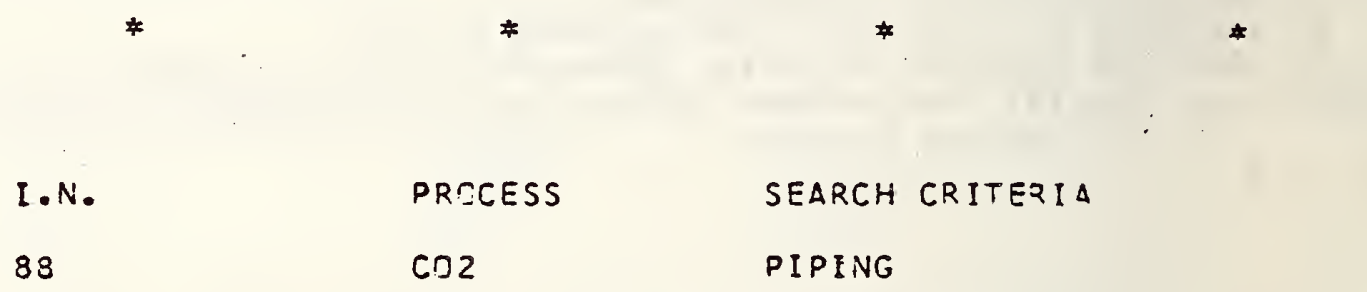

FAILURE REPORT BY L.WOLFE, CONOCO, $8 / 14 / 72$

METALLURGICAL STUDIES OF A RUPTURED INCDLOY 820 TUGE.

\section{SUMMARY}

A 50-FT LENGTH DF A85-FT. VERTICAL SECTINIV OF A 4-IN IO X 3/16 IN WALL THICK. INCOLOY 300 TUBINGILINE CD-208-4"-SICIWHICH CDNNECTS THE ENGAGER DOTT TO THE REGENFRATIR RUPTUPEDIFXPLTDED). THE LINE WAS USED FOR TPANSPDRTING P TWDERFD DOLOMITE AND LIGNITE AT ABEUT $1350 F$ AT A PRESSURE OF 150 PSI.THIS LINE WAS INSULATED AND ENCLOSED INN A CARBON! STCEL PIPE.MOST DF THE FRACTURED SAMPLES SHOWED SIGNS OF MELTING.THF UPPER DIRTION JF THE TUBE BROKE BRITTLYLY $\triangle I O N G$ GRAIN BOUNDARIES. ALL SAYPLES HAD TITANIUM SULFIDE PRECIPITATES IN THE GRAIN BCUNDAPIES IN BDTH THE HOT ZTINES AIJD THE CORLER ZTNES.THE ORIGINAL ALLOY WAS NOT DEFECTIVE OR ABNORMAL. 
FAILURE RSPGRT, $2 / 7 / 74,8 Y$ Q.PSRKINS AND W.C.JONS, LOCKHEED LAB TO CONSCL. MET. ANALYSIS OF COPRODEO INCOLOY 800 TUBE FRDM A RECYCLE GAS HEATER.

SUMMARY

MET. ANALYSIS OF CCRRJDED INCDLOY R.OO TUBE FROM \& RECYCLE GAS HEATER. THE TUBE HAD A VERY COMPLEX HISTIRY. NOT REPRESENTATIVE OF NORMAL OPERATING CONOITIONS.

1. THE PIPE HAS BEEN DEgRADED BY A COMBINATION OF CARBURIZATIDN. SULFIDATION, AND DXICATION.

2. CARBURIZATION IN DEPTH PRECEDED THE OTHFR REACTIONS AND ESTABLISHED A CR-RICH PHASE AT THE GRAIN BDUNDARIES.

3. INCOLOY 800 DOES NOT APPEAR TO HAVE ADEQUATE RESISTANCE TE OXIDATION IN THE ENVIZDNMENT FOR THIS APPLICATION. A HIGHER CR OLLOY HHICH CAN FJRM A MORE PROTECTIVE OXIDE FILM TI RETAPD THE DIFFUSION OF CARBON AND SULFUR. TO THE UNDERLYING METAL MAY GIVE BETTER PERFCRMANCE. ADDITIONS DF IL, TI, AND SI ALSO WOULD BE HELPFUL.

*

\begin{tabular}{lll} 
& \multicolumn{1}{c}{$*$} & \\
& & \\
I.N. & PROCESS & \\
94 & CO2 & SEARCH CRITERIA
\end{tabular}

LETTER REPORT, 4/9/74,FROM L.RICE,C.F.BRAUN,TO D.GLASER, STEARNS-ROGER. RISER EXPANSICN JOINT FAILURES.

SUMMARY

REMEDIAL RECOMMENDATICNS FOR PIPING EXPANSION JOINT SPECIALISTS.

1. WEAKNESSES DF PRESENT SLIP JOINT SET-UP.

A. PRESENT LOCATION WILL NOT PREVENT "JACK-KNIFING" .

B. ANY BINOING, SEIZING TR FRICTION AT THE JOINT WILL CAUSE BUCKLING AND OISTORTION CF THE TUBE DURINIG HEAT-UP AND SHUTDOWN.

2. CHANGES RECOMMENDED

A. THREE DESIGV SKETCHES ARE ATTACHED SHOWING PROPOSEO MOOIFICATIONS.

B. RECOMMEND THAT SLIP SLEEVES BE PURGED DOWNWARD RATHER THAN UPWAPD AS AT PRESENT. THIS WILL PREVENT SOLIDS FROM ENTEP.ING THE SLEEVE. 
I.N.

95
PROCESS

$\mathrm{CO} 2$
SEARCH CRITERIA

PIPING

FAILURE REDORT, $4 / 16 / 74, F P O M$ L.WDLFE, CONOCO,TO J.LETERLE, CONOCO. MICROPROBE AND METALLDGP.APHIC STUDIES OF PITTED FURNACE TUBES.

\section{SUMMARY}

MICROPROBE AND METALLOGRAPHIC STUDIES OF PITTED FIJPNACE TUBES. THE LIGNITE GAS. PLANT HAS HAD SEVSRE CORROSITN PRDBLFYS FROM HIGH TEMP. SULFUP. A ZINC OXIDE SYSTEM WAS INSTALLED FRQ REMIVING SULFUR. THI RUNS TITALING 150 HRS WERE MADE WITH VERY LON SULFUR GAS. DUR ING THESE PUNS THE INSIDE OF THE FURNACE TUBES WEP.E SEVERLY DITTED AND ONE BURST.

1. THE PITS APE IN CARBURIZED METAL CONCLUSIONS

2. DRIGINAL SURFACE HAS SOME SULFUR CORRDSION WHICH SEEMS TO RETARD THE CARBURIZATION AND PITTING.

3. MOST PIT SURFACES ARE COVERED WITH BLACK, MAGNETIC SCALE WHICH IS OFTEN IN TWO DISTIYCT LAYFRS.

4. THE OUTER, THICKER SCALE IS PAOTICLES OF METAL AND METAL DXIDES.

5. THE INNER SCQLE IS A THIN LAYER OF CR-RICH OXIDE WHICH CONTAINS SOME IRON.

6. TUBES OF INCOLOY 8OO AND 321 S.S. PITTED SIMILARY.

7. THIS ATTACK LIOKS SIMILAR TO "METAL DUSTING" WHICH DESCIBES THE SCAIE AS GPAPHITE WITH METAL PARTICLES. THE PAPIO CITY SCALE IS CR-DEPLETED METAL PARTICLES WHICH ARE PARTIALLY OXIDIZED.

$\neq$

\begin{tabular}{lll} 
& \multicolumn{1}{c}{$*$} & \\
I.N. & & \\
102 & PROCESS & SEARCH CRITERIA \\
& CD2 & PIPING
\end{tabular}

FAILURE REPORT FRDM F.RADD TO C.FINK, CONOCO, $5 / 30 / 74$. INCOLOY $8 O O$ HEATER COILS

\section{SUMMARY}

HIGH TEMPERATURE CORROSIDY CAUSATIVE AND CDNTRCL ANALYSIS FIR INCOLOY BNO ALLOY HEATER COILS. MANY ALLOYS ART SUB.JECT TD AN EXTREMELY VIPULENT FORM OF HIGH TEMOERATURE OITTING ATTACK ("METAL DUSTING"). AN INCOLDY $320^{\circ}$ HEATER COIL SUFFERED A HIGH TEMP. CORROSIOV FAILURE WITH DEEP SPHER ICAL PITS WHICH COVERED 30-40\% OF THE SURFACE. THIS CCIL. WAS SU9JECTEO TO AN ASSESSMENT OF THE MAJOR CONTROLLING VARIABLES AND THE PRINCIPAL CAUSATIVE MECHANISYS INVOLVED THAT COULD LFAD TE SUCH AV ATTACK. METALLOGRAPHIC. $X$-RAY DIFFRACTION, AIND X-QAY MICROPROBE ANALYSES WERE USED IN THE EXAMINATION OF THE.CIIL. EXPLANATIONS ARE GIVEN TO EXPLAIN THE CAUSE TF THE "METAL DUSTING" PHENOMENINN. 


$\begin{array}{lll}\text { I.N. } & \text { PROCESS } & \text { SEARCH CRITERIA } \\ 112 & C O 2 & \text { PIPING }\end{array}$

FINAL REPORT FROM D. QUALLS TO J.LETERLE,CONOCD.11/7/74.

EVALUATION OF HEATER. TUBES FROM RAPIO CITY CONSDL

SUMMARY

EVALUATION OF HEATER TUBES FROM RADIO CITY CONSOL

FIVE HEATER TUBE SAIAPLES WERE SUBMITTED.THEY HAD BEEN INSPECTED BY MAGNFTIC INSPECTION WHICH INDICATED SOME DAHAGE.

A MICROSTRUCTURAL EVALUATION WAS REQUESTED TO CORRELATE ACTUAL DAMAGE HITH MAGNETIC INSPECTION RESULTS.

ALONIZSD 304 S.S. TUBE WAS GODN.THE FOUR SAMPLES OF INCQL TY 9OO TUBING CONTAINED VARYING DEGPEES OF CORROSION AND STRUCTURAL DAMAGE.THF. DAMAGE WAS < 12.27 OF THE MINIMUM MEASURED HALL THICKNESS.

*

\begin{tabular}{lll} 
& \multicolumn{1}{c}{$*$} & \\
I.N. & PRECESS & SEARCH CRITEPIA \\
130 & CO2 & PIPING
\end{tabular}

ERDA MAT. AND COHP .FAIL.REPCRT, 3/25/75, FROH C.SCHULZ, CD2. 3-205 ACCEPTOR LIFT HEATER

SUMMARY

FAILURE: THE FLJA IN THPEE PASSES DF THE FURVACE WAS CONSTRICTFD DUE TS VERY SEVERE SCALING. THE RUN TERMINATED DUE TO EXCESSIVE PRESSURE DRTP ACRISS

THE CDIL DUE TO ABTVE SCALINIG. SERVICE LIFE: 1699 HRS ENVIRONMENT: TEMP. 11OC-140OF. GAS COMPOSITION-3-4Z CO, 26\% CN2, 7DF N2. CARBONYL SULFIDE 5? PPM NOMINAL (RANGES FRDY TRACE TD 400 PPY). MATERIAL CF CONSTRUCTION: INCNLOY 300 . CAUSE OF FAILURE: UNKANOWN. ACTION: DIAGNOSTIC ANALYSIS TO BE PERFORMED BY CONOCO. 


$\begin{array}{lll}\text { 1.N. } & \text { PROCESS } & \text { SEARCH CRITERIA } \\ 148 . & \text { CO2 } & \text { PIPING }\end{array}$

ERDA MAT.AND COMP.FAIL.REPCRT.CO2 .C. SCHULZ . 10/8/75. REBUILT B-2C.5 ALPHA FURNACE COIL

SUMMARY

FAILUPE: A 9-FT 9-IN SECTION OF OLD MATERIAL IN THE "A" PASS WAS REPLACEO DUE TO THINNING $\triangle M D$ A SMALL PIN HOLE.

SERVICE LIFE: 581 HRS SINCF REBUILD.

PRIOR REPAIRS: COIL WAS RERUILT REPLACING ALL THIN SECTIONS IN DEC. 1974 HITH ALDNIZED RA-33\%.

ENVIRCNMENT: TEMP. 1000-150DF. INERT GAS (83-87\% N2, 6-12R C $22,0.2-9.6 \% 02)$ AND RECYCLE GAS (3O\% N2, 17\% CO2, 3\% CJ, CARBONYL SULFIDE 50 PPM). MATERIALS OF CONSTRUCTICN: INCOLOY 800 WITH SECTIONS OF ALONIZER RA-33?. CAUSE OF FAILURE: PROBABLY DUE TO CARBURIZATION ANO SULF IDATIJN. ACTION: DIAGNOSTIC ANALYSIS TO RE PERFORMEO BY CONOCO.

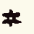

EROA MAT. AND COMP .FAIL.REPORT, 10/17/75, FRDY C.SCHULZ,COZ. REBUILT B-205 ALPHA FURNACE COIL

\section{SUMMARY}

FAILURE: THE TUBE WALLS IN SEVERAL AREAS HAD GREATLY. THINNED REQUIRING REPLACEMENT OF THE CDIL. SERVICE LIFE: 919 HRS SINCE REBUILDING ENVIRONMENT: SEE ATTACHMENT FOYR HRS AND TYPES OF ATMOSPHERE PRIOR REPAIRS: COIL WAS REBUILT REPLACING ALL THIN SECTIONS, 12/74, WITH ALONIZED RA 330 AND A 9 I-I" SECTION WAS REPLACED $9 / 75$. MATERIALS: INCOL?Y 800 AN!D $2 A 330$ CONCLUSIONS: THINNING WAS PRTBABLY DUE TO A CQMBINATION OF RARBURIZATION AND SULFIDATION.NEW COIL FABRICATED DUT OF INCONEL 702 . ACTION: REPLACED PART. ANAI.YSIS BY COMPANY LABS. 


$\begin{array}{lll}\text { I.N. } & \text { PROCESS } & \text { SEARCH CRITERIA } \\ 161 & \text { CO2 } & \text { PIPING }\end{array}$

REPORT BY R.PERKINS AND W.COONS, 11/19/75.METALLURGICAL AYALYSIS OF INCOLOY 8OO TUBE FROM B-2OI 14 HEATFR COIL AFTER RUNS 2O-2\%.

\section{SUMMARY}

METALLURGICAL ANALYSIS DF INCCLOY 300 TURE FRDH B-2OL-1A HEATER CDII. AFTFR RUNS 20-22. FOLLOW-UP TO PREVIJUS LOCKHEED REPORT (L.4SC-0407190). THAT REPORT DESCRIRED PITTING IN THE COIL UP TO RUN NO. 19. THE ANALYSIS IN THIS REPORT WAS FRDM A SAMPLE TAKEN AFTER RUN NO. 22. CCNCLUSIONS

1. PREEXISTING PITS DID NOT GRON IN SIZE AND NEW PITS OID NIT FORM DURING A 5IC-HR EXPOSURE DF INCOLDY 80? PIPE TO RECYCLE GAS WITH THE LDOITION OF 30-50\% STEAM.

2. THERE WAS NO SIGVIFICANT INCREASE IN THE AMOUNT DF INTERNAL CARBURIZATIDN AND SULFIDATIIN OUQING THIS EXPISURE.

3. THE ADOITIJN OF $>32 \%$ STEAM TO THE PECYCLE GAS COUPLED WITH LITTLE, IF ANY EXPOSURE TO ALTERNATE REDUCING/OXIDIZING CCNIDITIONS APPEARS TO BE RESPONSIBLE FOR THE GOOD RESISTANCE TO HIGH-TEMPERATURE PITTIPHG. 


$\begin{array}{lll}\text { I.N. } & \text { PRCCESS } & \text { SEARCH CRITERIA } \\ 176 & \text { HYGAS } & \text { PIPING }\end{array}$

EROA MAT. AND COMP.FAIL. REOORT, 10/13/76,FROM W. ORCHARD, IGT . PIPING FAILURE-ZND STAGE GASIFIER REACTOR

\section{SU:AMARY}

FAILURE: PIPE HAS ALMIST 360 DEGREE CIRCUMFERENTIAL BREAK IMMEDIATELY ADJACENT TO 0.0. WELO OF UPPER FLANGE, ALSO SOME LONGITUOINAL CRACKS ON I.0. DF PIPE INSIDE SAME FLANGE.

SERVICE LIFE: $1-1 / 2$ TO 2 YEAPS DF INTERMITTENT SERVICE.

ENVIRONMENT: CHAR PLUS SYNTHESIS GAS AT ABDUT $1502 \mathrm{~F} / 72 \% \mathrm{H} 20.93 \mathrm{CH} 4.4 \% \mathrm{CO}$. 3\% $\mathrm{CO}$, 3\% $\mathrm{NL},<$ 1: H2SI.

MATERIALS OF CONSTRUCTION: 53" LENGTH DF 3" SCH. 40 PIPEIRA 330 OR INCOLDY 3ON) EACH END HAVING A 156 LS $316 \mathrm{~S} .5$. SLIP-ON FLANGE(WELDED WITH 312 DR 182 RCD). CAUSE: BENDING FATIGUE.LO'NER END DF THIS VERTICAL PIPE HANGS FREE INSIDE FLUIDIZED BED.

ACTION: REPLACED PART. ANALYSIS BY ARGCNINE NATICNAL LAB.

* 


$\begin{array}{lll}\text { I.N. } & \text { PROCESS } & \text { SEARCH CPITERIA } \\ 224 & \text { LIGNITE } & \text { PIPING }\end{array}$

LETTER, 5/12/76, FROM D.SEVERSON, PROJECT LIGNITE, TO N.BERLIN, RALPH PARSONS. PERSONNEL PROTECTION-PROJECT LIGNITE

\section{SUMMARY}

EXAMPLES OF SAFETY MEASURES UNDERTAKEN AT PRO JECT LIGNITE FIR PFRSONNEL PROTECTION.THE SINGLE HCST SEP. IOUS POTENTIAL HAZARD IS CO WHICH IS BOTH TOXIC AND FLAMHABLE.METHODS OF DEALING WITH THIS PROBLEY ADE DISCUSSED. SECTIONS OF INCDLOY BOO TUZING FRJM THE PDU HAVE BEEN EXAMINE? PERIODICALLY AND TO DATE(5/12/76)THEOE HAVE 3 SEN NO INDICATIONS DF THE SCC THAT PLAGUED THE 316 S.S. TUBING.

SEE I.N.215 AND 225 FOR ADOITIONAL CDMMENTS. 


$\begin{array}{lll}\text { I.N. } & \text { PROCESS } & \text { SEARCH CRITERIA } \\ 37.0 & \text { SRC } & \text { PIPING }\end{array}$

TRIP REPDRT, 2/16/77,FRIM R.KING \& R.CMOPER TD G.SLAUGHTER, CRRL. REPORT ON TRIP TO SRC PILOT PLANT AT TACOMA, WISH.

\section{SUMMARY}

A. SLURRY PREHEATER. COIL

\section{SRC PILOT PLANT PROBLEM AREAS}

1. > 20 FT HIGH X 1? FT DIAM.,1309-1700 FT LONG,3" X SCHFDULE XX INCRLOY 800 HELICAL COIL, WITH BUTT WELDS.

2. PROBLEM IS AMDUNT GF COKING THAT OCCURS IN THIS COIL. IS IT SIGNIFICANT?

3. DRNL WILL TRY TO DEVELOP NOT METHOOS FOR TESTING FOR COKING.CORROSION AND STRESS CDRROSION IN. THE COIL.

B. PARTIALLY CDKED ELBDW

1. 5-D,4" SCHED. XX 347 S.S. (COLD FORMEO NOT STFESS RELIEVEO) ELBOW.

2. OPERATING TEMP. 750-800 F.90: PLUGGED BY A HARD RESIDUE.

3. IF ELBOW PLUGS THE PRDCESS IS SHUTDDWN.ONE PIPE HAS RUPTURED DUE TO AUTOMATIC HEATING OF $A$ PLUGGFO PRESSURIZED LINE.

4. ORNL HAS A SECTION OF PLUGGED ELBGN FDR ANALYSIS.

C. DISSOLVER

I. A 347 S.S. LINER IN THE NOZZLE, WELDED TO A fLANGE THAT IS ATTACHED TO THE OVERLAY.

2. THE LINER-FLANGE WELO HAS CRACKED.POSSIBILITY EXISTS OF CORRTSIVE ATTACK BENEATH THE SLEEVE.

3. ORNL WILL SUPPLY NDE GUIDANCE AND POSSIBLY FIELD EXAMINATION.

D. PRESSURE LETDOWN VALVFS

1. I" FISCHER VALVESIDBO AND DBQAI WITH FLOW FROM LARGE TO SHALL DIAMETER.TRIM SETS ARE TUNGSTEN CARRIDE.

2. VALVES ARE FAILIHG SY EROSIDN ANID BPEAKAGE FROM LODGED PARTICLES.

3. ORNL HAS RECOMMENDED SOMS DESI GN! CHANGES.

4. FAILEO TRIM SETS WILL BE ANALYZED BY DRNL.

E. CENTRIFUGAL DIJMPS

1. OIERKO PUMPS WITH CD4MCO HJUSINGS ANN GOULO PUMPS WITH IZCR-HARDENFD STEEL CASES.REBIJILT AND FLAME SPRAYED WITH TUNGSTEN CARBIDE.

2. EROSION/CORPOSION FAILURES CCCUR IN APPROX. 33 DAYS.

3. ORNL STRONGLY RECRMMFNDS A PPOGRAM FOR EVALUATING WEAR RESISTANT MATERIALS DIRECTLY IN THE SPC PROCESS STREAM.SRC MANAGEMFNT WOULD PROBABLY SUPPDRT THIS PROPOSAL.

F. PRESSURE VESSFLS.

1. HIGH PRESSURE DRUM(1500 PSI)-2-1/4CR-190 STEEL WITH A 2 FT I.0. $X$ 5/6" THICK HEAD HAS A FD?GE BCNDED 304 S.S. CLAD.

2. STRESS CORROSIDN CRACKING DF HEAD IS PROBABLE.

3. INTERMEDIATE PRESSURE VESSEL (5CO PSI)-1/2MC STEEL 2 FT I.D. X 5/6"W.T.

4. CRACKING OF HEAD CLACDING IS VISIBLE.

5. ORNL COULD USE NDE TD DETERMIVE ATTACK DF SASE METAL.NEXT SHUTDOWN THE HEAD COULO BE SECTIONED FIR COMPLETE ANALYSIS.

G. FRACTIONATION AREA

1. PROCESS STREAM IS HIGHLY ACIOIC WITH NAPTHALIC ACID ATTACK AT ALL HOT AREAS BEING THE RULE.LO'N ALLOY STEELS AND $324 \mathrm{~S} . S$. ARE ATTACKED. 


$\begin{array}{lll}\text { I.N. } & \text { PROCESS } & \text { SEARCH CRITERIA } \\ 405 & \text { SYNTHANE } & \text { PIPING }\end{array}$

QUALITY ASSURANCE REPCRT, 5/31/77,FPIM J.JEWELL, LUMMUS. CRACKING IN INCOLOY BOO PIPE REDUCER

\section{SUMMARY}

FAILURE: NOZZLE NO.5O DEVELOPEO CRACKS IN THREE AREAS AROUND THE HELO.CEACKS APPEAR TO $8 E$ IV HAZ WHERE MONEL LINER IS WELDED TO INSIDE TF PEDUCER. SERVICE LIFE: SINCE INITIAL START-UP. ENVIRONMENT: 600 DSIG,SKIN TENPERATURE, 300-400 F, DOAL PRDOUCT GAS. MATERIAL: NOZZLE IS 3" IN DIAM. AND REDUCES TO 1-1/2" PIPE ANO FLANGE. INCOLOY 300 LINED WITH YONEL OVERLAY.

CAUSE: UNKNOWN.RFPIRT DUE LATER.

ACTION: FAULTY WELO AREA HAS BEEN CUT DUT AND WILL BE REPLACED BY $A$ 3" PIPE SECTION. WITHOUT THE REDUC?R.

SEE I.N. 410 FOR FURTHER ANALYSIS OF FAILURE.

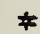

$$
I . N \text {. }
$$

410
PRSCESS

SYNTHANE
SEARCH CRITERIA

PIPING

MEMO, T/I/T7, FROM R .DOB3YN, NBS, TO H.FRANKEL, ERDA. .

CRACKING IN AN INCOLOY 300 REOUCER-SYNTHANE PILOT PLANT

$$
\text { SUMMARY. }
$$

SEE I.N. 405 FOR INITIAL FAILURE REPORT.

FAILURE MODE: METALLOGRAPHIC EXAMINATION BY C.E.LUMMUS INDICATED THAT INTERGRANULAR STRESS CRRRDSION CRICKING WAS THE CAUSE TIF FAILURE. IN ADOITION, THE AS-RECEIVEO INCOLOY SOO RASE METAL WAS SENSITIZED. RECOMMENDATIONS

1. REMOVE NOZZLES 39 AND 41 INCLUDING FLANGES AND RING JOINTS FOR EXAMINATIOV BY LUMMUS.

2. INITIATE REPLACEMENT OF NDZZLES USING MONEL-LINED COMPONENTS IN COMBINATION WITH ON-HAND INCOLOY COMPONENTS.ALL INCJLOY $9 O O$ USED WILL BE SOLUTION ANNEALEO ANO QUEVCHEO.

3. THIS WILL REQUTRE A SHUTDOWN OF APPROXIMATELY 5 WEEKS.DURING THIS TIME VARIOUS OTHER MAINTENANCE ANO REPAIR TASKS HILL BE COMPLETED. 
I.N.

351
PROCESS

WEST INGHOUSE
SEARCH CRITERIA

PIPING

ERDA MAT . AND COMP .FAIL.RSPDRT, $2 / 8 / 77$, FROH E.VANDERGRIFT , WESTINGHNUSE. PIPING FAILURE-CHAR/RECYCLE GAS LINE

\section{SUMMARY}

FAILURE: 1/32" CIAM. HDLE DEVELOPED IN "Y" BRANCH OF DOLOMITE DIVERSION PIPE LINE.

SERVICE LIFE: 30 HRS.

ENVIRONMENT: 120J F.DEAN BURNED DDLOMITE.24? PSIG.

MATERIAL: GI-INCH SCHEDULE 40 INCOLOY $8 C O$ PIPE.

CAUSE: 45 DEGREE "Y" BRANCH INTERNALLY ERDDED DUE TO ABRASION TF MATERIAL. ACTION: REPLACED PART. ANGLE OF BRAIVH CHANGED TO $9 O$ DEGREES IN DRDER TO

REDIICE IMPACT VELDCITIES. ANALYSIS TO BE DONE BY COMPANY LABS.

I.N. PROCESS SEARCH CRITERIA

353 . WESTINGHIUSE PIPING

ERDA MAT. AND COMP.FAIL.REPORT, 3/10/77,FROM E.VANOERGRIFT , WESTINGHOUSE. PIPING FAILURE-RGS-25

\section{SUMMARY}

FAILURE: CRACK IN PIPE 1/32" WIDE, ?/3 OF CIRCUMFERENCE,7/8" FROM FLANGE TO FII4 HEATEP. SERVICE LIFE: 2 YEARS. ENVIRDNMENT: 525 F MAX.RECIRCULATIVG GAS.

MATERIAL OF CONSTRUCTION: INCOLDY $832.1 "$ DIAM. PIPE.

CAUSE: FAILURF IN HAZ NEAF WELD. YATERIAL FLAW.FAILURE CAUSED OY VIBRATION INDUCED CRACK PROPAGATIDN.

ACTION: REPLACED PART. SAVED. VO ANALYSIS.

SEE I.N. 409 FOR ANALYSIS OF PIPIYG FAILURE. 


$\begin{array}{lll}\text { I.N. } & \text { PRCCESS } & \text { SEARCH CRITERIA } \\ 499 & \text { WESTINGHOUSE . PIPING }\end{array}$

MEYO, 6/21/77, FRDM T. COX TO M. CARRINGTON, ERDA

CRACKING OF INCOLOY 800 PIPING IN WESTINGHDUSE PDU

SUMMARY

FAILURE: SIX FAILURES HAVE 3CCURRE? IN THE I-INCH, SCHEDULE 40 PIPE IN THE TRANSPORT LINES. FIUP. FAILURES HAVE DCCURRED IN THE 4-INCH, SCHEDULF 40 PIPE IN THE TRANSPRRT LINES. FIUR FAILURES HAVE DCCUPRED IN THE 2-INCH SCHEDULE 40 PIPE IN THE VENT PIPING. FAILURE CAUSE WAS CPACKING WHICH QCCURSED CLOSE TO WELOS, BUT NOT VECESSARILY IN THE WELD METAL OR HAZ. SERVICE LIFE: FAILURES DCCURRED OVER A PERIOD OF SEVERAL HIJNDRED HCURS OF OPERATIINN.

ENVIRDNMENT: MAXIMUM TEMPERATURE IS 6OOF.

MATERIAL: INCOLOY 303

CAUSE: EVIDENCE INDICATES THAT THE FAILURES RESULTED FRMM INTERGRANULAE. STRESS CORROSION CRACKING. EXAI YINATION REVEALED THAT THE ?NCOLOY BON WAS HIGHLY SEVSITIZED. RESIDUSL STRESSES MAY BE DUE TO THE WELDING OPERATION OR. TO IMPOSEO STRESSES DIJPING INSTALLATION.

THE CORRODING AGENT HAS NOT BEEN IDFNTIFIED.

RECDMMENDATINNS

1. SENSITIZEO PIPIM!G MUST BE ELIMINIATED.

2. REPLACE WITH SOLUTION ANNEALED AND QUENCHED MATERIAL WELDED USING A DROCEDURE TO AVNIO SENSITIZATION IN THE HAZ.

3. EFFCRTS SHDULD BE YADE TO IDEVTIFY THE CORRODING $\triangle G E N T$.

4. COLLECTION POINTS SHOULD BE INSTALLED AT SUITABLE POSITIONS IN THE. PDU FCR OBTAIVING SAMPLES CF THE CONDENSATES WHICH FORM IN THE LINES. SEEI.N. 353 FOR INITIAL REPORT OF ONE DF THE PIPING FAILURTS.
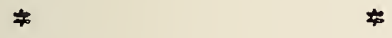

PRESSURE VESSELS 

I.N.

13
PROCESS

HYGAS
SEARCH CRITERIA

PRESSURE VESSEL

FAILURE ANALYSIS REPCRT,11/30/73,FROM M.HOWES, IITRI,TJ F.SCHORA, IGT. METALLOGRAPHIC EXAMINATION DF FIVE SAMPLES FRDM THE HYGAS PLANT

\section{SUMMARY}

1. SLURRY DRYER GRID: INCOLOY 800. SERVICE LIFE OF 6 MONTHS.ENVIROAMENT, LIGNITE BED AT 600 F FLUIOIZED WITH A GASICONTAINS 1: HLSI AT IZDO F AND 1000 PSI.FAILURE OCCURREO BY CCRROSION AT SCREN THREADS.RECOMMEND COATINE ANC REDESIGN TO ELIMINATE SCREW THREAOS.

2. WELDED $4 \times 3$ IN REDUCER: 446 S.S. SERVICE LIFE OF 6 MDNTHS.ENVIRTNMFNT. $1500 \mathrm{~F}$ AT 25 PSI, FLUTOIZED LIGNITE-INTERNAL, NITROGEN-EXTERNAL.FA ILURE CAUSED BY CRACK THAT STARTED IN THE WELD BETWEEN THE PIPE AND FLANGE AND PROPAGATED IN BDTH DIOECTIONS.REASON BFING MATERIAL EMBRITTLEMENT AND RESICUAL STRESSES.RECOMMEND STRESS RELIEVING.

3. BELLCWS: INCOLOY 800120 GAUGE). SERVICE LIFE OF 9 MONTHS. ENVIRONMENT. $1650 \mathrm{~F}$ IN A CORROSIVE ATMOSPHERE. FAILURE OCCURREO BY COMBINATION OF SURFACE OXIOATION AND INTERGRANULAR ATTACK RECOMMEND REDESIGY.

4. REFCRMER QUENCH POT SHELL: INCOI.JY 80J. SFRVICE LIFE OF 6 YDNTHS.ENVIQDNMENT, $1650 \mathrm{~F}$ AT $10 J$ PSI.FAILURE DUE T! THERMIL FATIGUE CAUSF. 3 Y FLUCTUATING TEMPERATURE CONDITIONS.RECIMMEND REDESIGN.

5. BUTTEPFLY VALVE: 446 S.S. SERVICE LIFE DF 2 YEARS.ENVIRON.AENT, $1400 \mathrm{~F}$. FAILURE DUE TO INTERNAL CORRDSION ANO RESIDUAL STRFSSES RFCDMMENO STRESS RELIEVING. 
I.N.

258
PROCESS

SYNTHANE
SEARCH CRITERIA

PRESSURE VESSEL

EROA MAT. ANO COMP.FAIL. PEPORT,10/18/76, FROY J.JEWELL, BRUCETDN. GASIFIER SHRDUD

\section{SUMMARY}

FAILURE: GASIFIEP. SH?DUD BUCKLED

SERVICE LIFE: D.2 IN 94 HRS TO DATE, IB-1/2 HRS ON LAST RUN

ENVIRONMENT: HS STEAM, C2, COAL $\triangle T$ ISOOF.RUN M.

MATERIAL: 1/8" THICK INCOL.OY $8004(5 B-409-900$ GR 2 ANNEALED)

CAUSE: EQUIPMENT MALFUNCTIOV. OVERHEATING FAILURE.

ACTIDN: REPLACED SHREUD.REPORT EXPECTED BY $1 / 2 / 77$.

廿

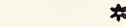

$I \cdot N$.

PROCESS

SEARCH CRITER I A

377

SYNTHANE

PRESSURE VESSEL

QUALITY ASSURANCE REPCRT,4:23/77,BY J.JENELL,LUMYUS.

BUCKLED GASIFIER SHRTUN

SUMMARY.

FAILURE: CRACKS WERE FOUNO IN THE HELO BETWEEN THE INTERFACE WITH THE CDNE. SERVICE LIFE: 450 HRS OF OXYGEN.

ENVIRONMENT: COAL DUST, OXYGEN,STEAM,600 PSIG, $1500 \mathrm{~F}$.

PRIOR REPAIR: SHROUD HAS BUCKLED PREVIDUSLY.

MATERIAL: INCOLOY 8Oก

CAUSE: INTERNAL STRESS AYO THERMAL STRESSES CAUSED RY BUCKLED SHRTUU LED

TO WEL F FAILURE.

ACTION: PRESS SHROUO BICK INTO POSITION AND PEEHELO.

COMMENT: THOUGHT SHZULO BE. GIVEN T.7 A NFW DESIGM. ONE HITH LOOSE PLATFS, TA ALLOW FOR EXPANSION AND CONTRACTION.PRESENT DESIGN ALLOWS NO ROQM FOR EXPANSION. 


$\begin{array}{lll}\text { I.N. } & \text { PROCESS } & \text { SEARCH CRITERI } \\ 404 & \text { SYNTHANE } & \text { PRESSURE VESSEL }\end{array}$

INTEROFFICE MEMO,5/9/7T,FROY W.VAN SWER INGEN TO P.STREBINGER, LUM,MUS. CRACKING IN GASIFIER SHRCUDS

\section{SUMPAARY}

CRACKS HAVE APDEAPEO IN THE CYLINDRICAL INCOLDY 800 MANWAY SHROUDS TN THE 7TH AND LOTH FLOORS.THESE CRACKS RUN CIRCUMFERENTIALLY FROM 8:00 TD 4:00 ANO ARE $\triangle P P R O X$. 3/4" AWAY FROM THE GASIFIER SHELL.THERE ARE SEVERAL SHIPT AXIAL CRACKS BRANCHIMG FRIM THE MAIN CRACK POSSIBLY CAUSED BY DTTEMPTEO WELD REPAIRS.

THE CPACKING WAS DROBAGLY CAUSED BY THE SEVERE THERMAL GRADIENT THAT EXISTS IN THE SHROUO(APPROX. 1400-?00 F OVER 9"1) BETWEEN THE INSIDE JF THE CASTABLE AMD THE SHELL.ANOTHER HYPJTHESIS IS THAT CRACKING OCCURRED FROM A COMBI':ATITN OF EFFECTS-DIRECT THERMAL STRESSES,CYCLIC HEATING ANO COOLING, AND VIBRATION FATIGIJE.

IT WAS CONCLUDED THAT THE CRACKS HILL DO LITTLE HARM.3/8" HOLES WILL BE DRILLED AT THE EAD DF EACH CRACK TI STCP ITS PROPAGATION.

SEE I.N. $377,393,399$ FOR $\triangle D D I T I O N A L$ INFORMATICN.
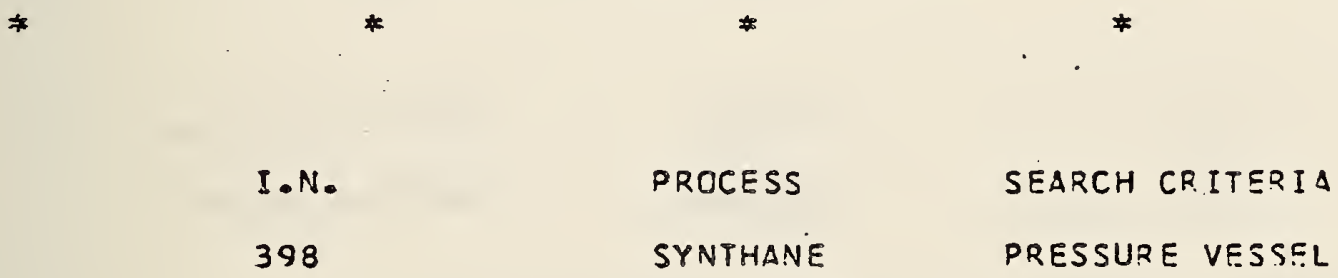

QUALITY ASSURANCE REPORT, 5/13/77,FROM J.JEWELL,LUMMUS.

EROSION DF GASIFIFP CYCLONE

\section{SUMMARY}

FAILURE: HOLE FCUND IN COUE SECTINN DF CYCLONE.AFTER REMOVAL DF THE CYCLONE A GENERAL EROSION PATTERN WAS FOUND. SERVICE LIFE: $\triangle P D R O X .1000$ HRS.

ENVIRONIENT: 800 F,DRJDUCT GAS,CHAR AND COAL OUST.600 PSIG. MATERIAL: INCOLOY $800:$

CAUSE: EROSIOV.

ACTION: REPAIREO BY $\triangle$ DOING TWO CONICAL COLLARS 1/8" THICK OVER ENTIRE CONE AREA. 


$\begin{array}{lll}\text { I.N. } & \text { PROCESS } & \text { SEARCH CRITERIA } \\ 399 & \text { SYNTHANE } & \text { PRESSURE VESSEL }\end{array}$

QUALITY ASSURINCE REOQRT, 5/13/77,FROM R.LORD, LUYMUS. CRACK IN GASIFIER SHRCUD

\section{SUMMARY}

FAILURE: CRACK IN SHRQUDING IN 7TH FLODR MANWAY FROM 8:00 TO 4:00 PCSITICN. CRACK NEAR SHROUD TO SHELL WELD ABOUT 1/8" WIDF.

SERVICE LIEE: UNKNOWN.

ENVIRONMENT: UNKNOWN.

MATERIAL: INCOLOY 802.

CAUSE: APPAREVT CAUSE TF FAILURE WAS THERMAL STRESSES.

ACTIDN: LEAVE AS IS FOR NEXT RUN, REPAIR, AND INSTALL NEW REFRACTDRY DURIMG NEXT SHUTDONN.

COMMENTS: 3/16" HCLES WERE DRILLED AT THE ENDS DF THE CRACKS THROUGH THE.

SHRCUD TD PREVENT FURTHER CRACKING.

SEE I.N. 377,393 FOR PREVIOUS REDORTS ON THIS PROBLEM.

†

I.N.

393

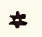

PRICESS

SYNTHANE
SEARCH CRITERIA

PRESSURE VESSEI.

QUALITY ASSURRANCE REPTRT, 5/24/77, FRCM J.JEWELL,LUMMUS.

GASIFIER-EUCKLED SHRQUD

\section{SUMMARY *}

FAILURE: THE INNER SHRTIJO IN THE REACTICN ZONE HAS BEEN BUCKLED FOR SOME TIME. IT IS BEL IFVED THAT THE SULGES INTERFEPE WITH THE FLUIDIZED BED AND POSSIBLY CAUSE THE FIRMATION OF CLINKERS.

SERVICE LIFE: 400 HRS.

ENVIRONHEMT: 1503 F,GO3 PSIG, COAL GAS,OL, STEAM, COAL CHAR. MATERIAL: INCOLOY $9 O O$.

CAUSE: DREVINUS REPORT INDICATES THAT A POTR DESIGN WHITH FAILS TD ALLDW FOR THERMAL EXPANSIION IS THE CONTR IBUTING FACTDR.SEE I.N. 377.

ACTION: REMOVEO 70\% JF ALL SHRDUD. WELDED IN NEW SHRJUD 360 DEGREES AS SHOWN BY PHOTO.NO MENTION MADE DF DESIGN CHANGE. 
THERMMCOUPLES 


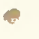




$\begin{array}{lll}\text { I.N. } & \text { PROCESS } & \text { SEARCH CRITEPIA } \\ 303 & \text { SYNTHANE } & \text { THERHOCOUPLES }\end{array}$

PRELIMINARY REPJRT, 7/26/76, FROM D.TUBIS TO B.LEWIS, SYNTHANE . GASIFIER DISTR IBUTOR CONE THER.YOCJUPLE FAILURE.

SUMMARY

SUMMARY OF PRELIMINARY REPJRT FROM S. DANYLUK, ANL.

1. THE FAILURE APPFAZS TD BE CAUSEO BY INTERGPANULAR CDRROSINN. THE CRACK STARTS AT DUTSIOE WALL AND PR?G?ESSES INWARD.

2. THIS FOFM OF CRACKING IS AGGPAVATED BY A HIGH SULFUR ENVIRINMENT.

3. MGO IS HYDROSCOPIC AND THE EXPANDING MOISTURE WILL COMPLETE THE TUBE SPLIT.

4. USE 310 OR 330 S.S. FDR BETTER CQRPOSION RESISTANCE. DEFINITELY NOT INCELOY 800.

5. CHECK ALL NEWLY INSTALLED THERMOCOUPLES WITH MAGNIFYING GLASS FOR CRACKS.

6. $A N L$ PLANS TO DO CHEMICAL ANALYSIS OF SHEATH MATERIAL. MGO AND CERROSION PROOUCT.

SEE I.N. 295, 298, 299, 300, 307, 308 FOR FURTHER INFORMATION.

屯

$\begin{array}{ccc} & * & * \\ \text { I.N. } & & \\ 300 & \text { PROCESS } & \text { SEARCH CRITEOIA } \\ & \text { SYNTHANE } & \text { THERMDCOUPLFS }\end{array}$

TELECON, 9/2/76,FRTM R.IVINS, ANL, TO B.ROCHE,LUMMUS.

FAILURE ANALYSIS OF DIST?IBUTION CONE THEPMCCOUPLE SHEATHS.

SUMMARY

ANL HAS CONTACTED THERMCCOUPLE SUPPLIER AND HDPES TO OBTAIN SAMPLES FRDM SAME BATCH AS FAILED THERMOCOUPLES.

G.STANTON IS TO BRING BACK SAMOLES FRTM A SECOND BATCH OF FAILED T/C SHEATHS. SEE I.N. $295,298,299,303,307,398$ FOR FURTHER INFORMATION. 
I.N.

308
PROCESS

SYNTHANE
SEARCH CRITERIA

THERMOC OUPLES

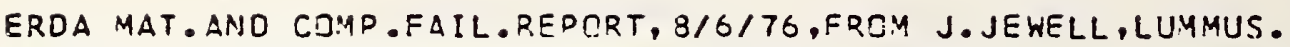
GASIFIER THERMOCNUPLE TE 268

\section{SUMMARY}

- FAILURE: SHEATH SEPARATEC, QPENED UP, EXTREME CORROSION. SERVICE LIFE: 17 HRS

ENVIRONMENT: 600 PSI,5OOF.STEAM AND DXYGEN-SDME ASH. MATER IAL: INCOLOY 80 ?

CAUSE: SHEATH MATERIAL VERY REACTIVE TO ENVIRONMENT. ACTIOV: REPLACED.DIAGNOSIS TO BE PERFORIVEO BY ANL. SEE I.N. $295,298,299,300,303,307$ FOR FURTHER INFIRMATION.

4

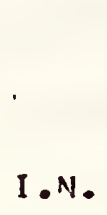

*
ঊ

PROCESS

319

SYNTHANE
SEARCH CRITE? IA

THERMOCOUPLES

TELECON, 9/3/76,FROM S.JANYLUK, ANL, TD B.LEWIS AND D. BAILEY, SYNTHANE. FAILURE ANALYSIS OF DIST?IBUTOR CNYE THERMOCOUPLE SHEATHS

SUMMARY

MICROHARDNESS MEASURFMENTS INDICATE COLD WORK AT FAILURE LCCATIMNS. GORROSION SCALE CONTAINS 1.4 WT ? SULFUR. FABRICATMR D?PS NOT UNOERSTAND SULFIDATION AT THE LOW QPERATING TEMPERATURES. LENIS STATED THAT NO. 2 FUEL OIL CONTAINING $2.25 \%$ SULFUR WAS USED FOP START-UP AT A TEMPERATURE MF $1000 \mathrm{~F}$. SINCE THIS COULD BE A PRORLEM, LENIS SUGGESTED AND I AGREEN, TH USE PROPANE AS THE START-IJP FUEL.

RECOHMENDATICNS: REPLACE INCOLOY 300 WITH 310 S.S.. BE CARFEIJL NOT TR

INTRDOUCF ADDITIONAL COLO WDRK IN THE MATERIAL BY BENDING THE TUBES

DURING INSTALLATION.

SEE I.N. 295, 299, 299, 3CO, 303, 307, 308, 312,318 FOR ADOITIDNAL DETAILS. 


$\begin{array}{lll}\text { I.N. PROCESS } & \text { SEARCH CRITEQIA } \\ 325 & \text { SYNTHANE } & \text { THERMOCOUPLES }\end{array}$

FINAL FAILIIRE ANALYSIS REPDRT, 10/76, FRDM. S.DANYLUKE G. ORAGEL, ANL. SYNTHANE GASIFIER. DISTR IBUTOR. CONE THERMOCOUPLE SHEATH(TF-268) FAILURFS

SUMMARY

FAILURE: CORROSISV CRACKS INITIATSD AT THE OD OF THE SHEATH MATERI LL AT SURFACE CP.ACKS DR. PITS. THE CR.ACKS PENETRATED TO THF ID SND THE VGN WAS EXPOSED TO STEAY. THESE CRACKS WIDENED BECIUSE OF FDRMATIONN OF MG(TH)2 WHICH HAS DOUBLE THE MOLECULAR VOLUME DF MGD. AS THE PRCCESS CONTINUED, THE SHEATH PLASTICALLY DEFORMEO AND RUDTURED ALDNG THE TUBE AXIS.

ENVIRONMENT: THE THERMECOUPLES ARS USED TI MONITTR DROCESS TEMDERATURE AND THE SHEATHS ARE NORMALLY EXPTSED TO A STEAM AND OXYGEN ENVIRONPENT. 600 PSIG AND G5OF.

MATERIALS OF CONSTPLCTIOY: CR-AL THER:ADCDUPLES WITH A SHEATH DF INCOL TY 800 AND MGO AS $\triangle N$ INSIJLATING MATERIAL.

CAUSE: A COMBINATIIV DF CORRISIVE ENYVIPONMENT, DFF-PRDCESS TEMPERATURES, SHEATH FABRICATION AND POSSIBLE COLD WDRKING OF THE SHEATHS CONTRIBUTED TO THE FAILURES.

RECOMMENDAT IONS

1. BETTER QUALITY CONTROL DF SHEATH FABP ICATIOV. USE STANDARD ISPEC. C7-6TI FOR METAL SHEATH, CERAMIC INSULATED THERMOCOUPLES.

2. A HIGHER CR S.S. (TYDE31O) SHCULO SOLVE THE SULFIDATION PRTRLEY. 3. SINCE THE FUEL DIL FOR START-UP CONTAINS SULFUR, SWITCH TI DRODANE. 4. CAREFUL HANDLING DF TUGES AND ANNEALING PRIOR TO INSTALLATION WOULD ELIMINATE THE CחLD WOPK. SEE I.N. 295, 298, 299, 300, 303, 307, 308, 312, 318, 319, FOQ PREVINUS REPORTS .

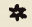


1.N.

337
PRDCESS

SYNTHANE
SEARCH CRITERIA

THERMOCOUPLES

LETTER W/COPY DF TC STANDARDS, $11 / 4 / 74, F R O M$ S.DANYLUK, ANL,TO B.ROCHE,LUMMUS. ROT STANDARD C7-6T W/SUPPLEMENTS

SUMMARY

THERMOCOUPLE MATERIAL AND THERMDCO'JPLE ASSEMBLY

CHROMEL-P VERSIUS ALUMEL

STAINLESS STEEL SHEATHED

MAGNESIUM OXIOE INSULATED

SEE SECTION ON SURFACE FINISH AND DEFECTS.IT DOES NOT ADPEAR THAT THE THERMDCOUPLE SHEATHS WE HAVE EXAMIVED WOULD HAVE MET THESE SPECIFICATIONS. IT MIGHT BE A GODD IDEA TJ USE THESE SPECS AS A GUIDE WHEN CRDER ING FUTURE MATER IAL.

$*$

I.N.

341
PROCESS

SYNTHANE
SEARCH CRITERIA

THERMOCOUPLES

TELECON, 11/29/76,FROM S.DANYLUK, ANL, TO B.MASSA,LUMMUS. SUBSTITUTE MATERIALS FOR $310 \mathrm{~S}$.S. TO BE USED IN GASIFIER

SUMMARY

310 S.S. WAS RECOMMENOEO AS A SUBSTITUTE FOR INCOLOY 800 THERMDCOUPLE SHEATHS WHICH WEDE FAILINIG IN SERVICE.HOWEVER, 310 S.S. SHEATHS WILL NOT BE AVAILABLE FOR SEVERAL MINTHS.446 S.S. WAS RECOMMENDED BUT EMBRITTLEMFNT MAY BE A PROBLEM. 
VALVES 



$\begin{array}{lll}\text { I.N. } & \text { PROCESS } & \text { SEARCH CRITEOIA } \\ 117 & \text { CO2 } & \text { VALVES }\end{array}$

ERDA MAT . AND COMP.FAIL.REPDRT, 1/31/75, FRJM C.SCHULZ, CO2. XCV-2010 AUTOMATIC VALVE

\section{SUMMARY}

FAILURE: THE LINER OF THE VALVE WAS ERTDED AWAY IN A SECTIJN 3" WIDE ON THE SOTTOM TO I" WIDE TN THE TOP DN ONF SIDE OF THE VALVE. SERVICE LIFE: APPREX. 9 MDNTHS.

ENVIRONMENT: TEMP. 145CF. VELDCITY 55-100 FT/SEC. ENTRAIVED DOLQATTE $8 \times 20$ MESH, RECYCLE GAS (CO, COL, N2) WITH SULFUR IN THE PPM RAHGE. MATERIAL OF CONSTRUCTION: INCOLOY 800

CAUSE OF FAILURE: THE INNER LINER WAS MISALIGNEO DUR ING MANIJFACTURE CAUSINS EROSION ON THE LINER.

ACTION: THE REPLACEMENT VALVE INIVER LINER WAS PROPERLY ALIGNED.

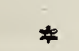





\begin{tabular}{|c|c|c|}
\hline $\begin{array}{l}\text { U.S. OEPT. OF COMM. } \\
\text { BIBLIOGRAPHIC DATA } \\
\text { SHEET }\end{array}$ & 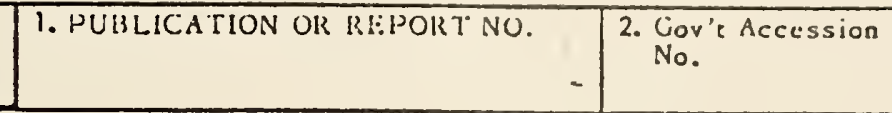 & 3. Kecipient's Aceessiun No. \\
\hline \multicolumn{2}{|l|}{ 4. TITLE AND SUBTITLE } & 5. Publication Date \\
\hline & 6. Performing Organizarion Code \\
\hline \multicolumn{2}{|c|}{$\begin{array}{l}\text { 7. AUTHOR(S) } \\
\text { William A. Willard and John H. Smith }\end{array}$} & 8. Performing Organ. Report No. \\
\hline \multirow{2}{*}{\multicolumn{2}{|c|}{$\begin{array}{l}\text { 9. PERFORMING ORGANIZATION NAME AND ADDRESS } \\
\text { NATIONAL BUREAU OF STANDARDS } \\
\text { DEPARTMENT OF COMMERCE } \\
\text { WASHINGTON, D.C. } 20234\end{array}$}} & $\begin{array}{l}\text { 10. Projecr/Task/Work Unit No. } \\
3120511\end{array}$ \\
\hline & & 11. Conerace/Grant No. \\
\hline \multirow{2}{*}{\multicolumn{2}{|c|}{$\begin{array}{l}\text { 12. Sponsoring Organization Name and Complete Address (Street, City, State, ZIP) } \\
\text { Energy Research and Development Administration } \\
20 \text { Massachusetts Avenue, N.W. } \\
\text { Washington, D.C. } 20545\end{array}$}} & $\begin{array}{l}\text { 13. Type of Report \& Period } \\
\text { Covered } \\
\text { Summary Report to } 6 / 77\end{array}$ \\
\hline & & 14. Sponsoring Agency Code \\
\hline
\end{tabular}

15. SUPPLEMENTARY NOTES

16. ABSTRACT (A 200-word or less factual summary of most significant in formation. If document includes a significant bibliography or literature survey, mention it here.)

This report consists of a group of summaries of operating experiences at coal conversion pilot plants, materials evaluation reports, and diagnostic failure analysis reports dealing with the use of Incoloy 800 in coal conversion processes.

17. KEY WORDS (six to twelve entries; alphabetical order; capitalize only the first letter of the first key word unless a proper name; separated by semicolons)

Coal gasification; coal liquefaction; component failures; failure analysis; Incoloy 800; material evaluation

\section{AVAILABILITY \\ Unlimired}

For Official Distriburion. Do Not Release to NTIS

Order From Sup. of Doc., U.S. Government Printing Oifice Washington, D.C. 20.402, SD Car. No. C.13

Order From National Technical Information Service (NTIS) Springfield, Virginia 2215I

\begin{tabular}{|l|l|}
\hline $\begin{array}{l}\text { 19. SECURITY CLASS } \\
\text { (THIS REPURT) }\end{array}$ & 21. NO. OF PAGES \\
UNCL ASSIFIED & 22. Price \\
\hline $\begin{array}{l}\text { 20. SECURITY CLASS } \\
\text { (THIS PAGE) } \\
\text { UNCLASSIFIED }\end{array}$ & \\
\hline
\end{tabular}


6434 





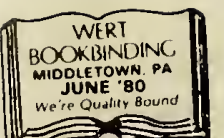


